Prepared in cooperation with the U.S. Fish and Wildlife Service

\title{
Hydraulic Modeling at Selected Dam-Removal and Culvert-Retrofit Sites in the Northeastern United States
}

Scientific Investigations Report 2021-5056

U.S. Department of the Interior U.S. Geological Survey 
Cover. Screenshot of two-dimensional hydraulic model at Hyde Pond Dam site on Whitford Brook, Mystic, Connecticut. The model was developed with the U.S. Army Corps of Engineers Hydrologic Engineering Center's River Analysis System software. 


\section{Hydraulic Modeling at Selected Dam-Removal and Culvert-Retrofit Sites in the Northeastern United States}

By Scott A. Olson and Caelan E. Simeone

Prepared in cooperation with the U.S. Fish and Wildlife Service

Scientific Investigations Report 2021-5056 


\section{U.S. Geological Survey, Reston, Virginia: 2021}

For more information on the USGS - the Federal source for science about the Earth, its natural and living resources, natural hazards, and the environment—visit https://www.usgs.gov or call 1-888-ASK-USGS.

For an overview of USGS information products, including maps, imagery, and publications, visit https://store.usgs.gov/.

Any use of trade, firm, or product names is for descriptive purposes only and does not imply endorsement by the U.S. Government.

Although this information product, for the most part, is in the public domain, it also may contain copyrighted materials as noted in the text. Permission to reproduce copyrighted items must be secured from the copyright owner.

Suggested citation:

Olson, S.A., and Simeone, C.E., 2021, Hydraulic modeling at selected dam-removal and culvert-retrofit sites in the northeastern United States: U.S. Geological Survey Scientific Investigations Report 2021-5056, 37 p., https://doi.org/10.3133/sir20215056.

Associated data for this publication:

Simeone, C.E., Olson, S.A., Taylor, N.J., Talbot, T.S., and Kinsey, J.M., 2021, Data and hydraulic models at selected dam removal and culvert retrofit sites in the northeastern United States: U.S. Geological Survey data release, https://doi.org/10.5066/P9LWIWV0.

ISSN 2328-0328 (online) 


\section{Contents}

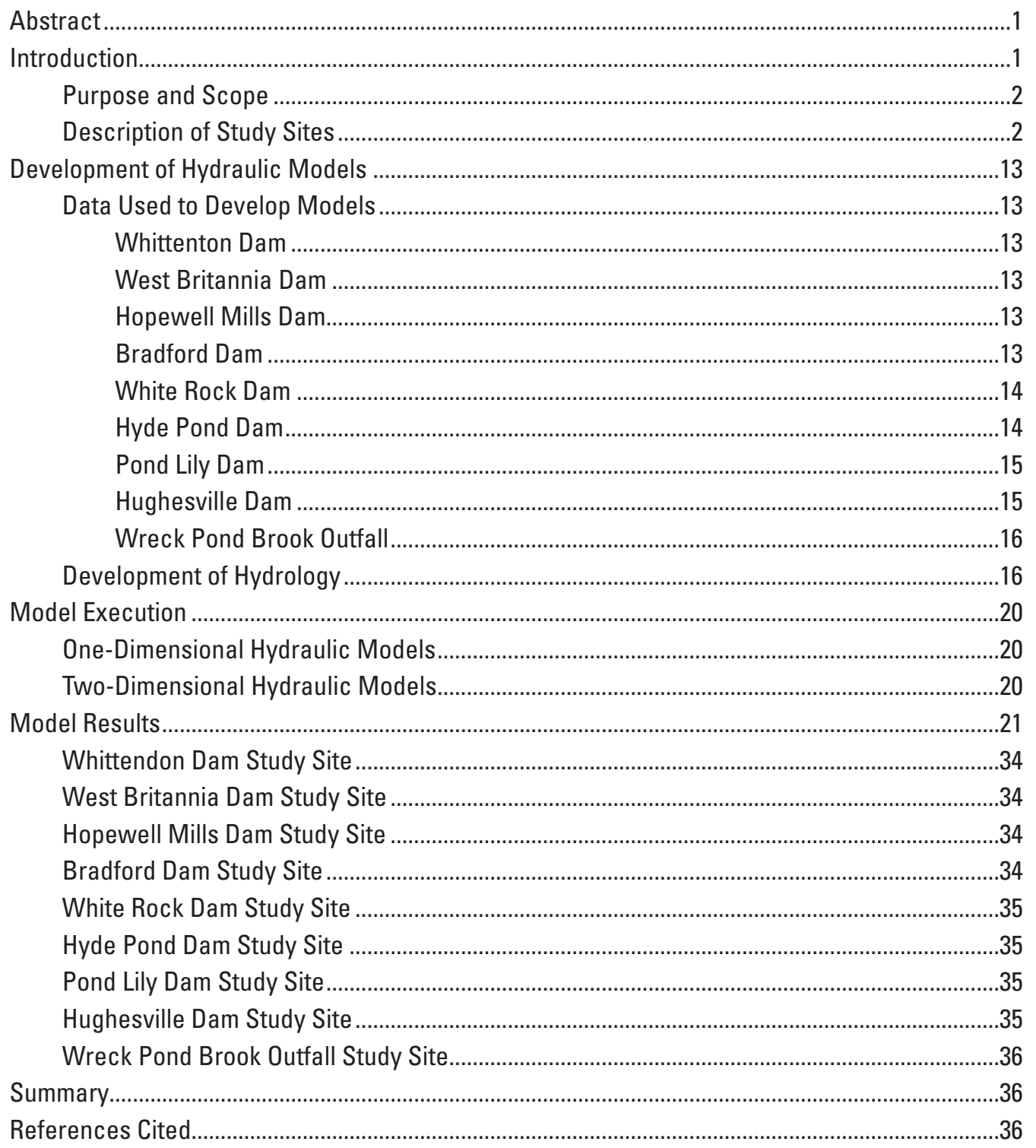

\section{Figures}

1. Map showing locations of the nine study sites in Massachusetts, Rhode Island, Connecticut, and New Jersey.

2. Map showing inundation areas of the 1-percent annual exceedance probability discharge at the Whittenton Dam study site, Taunton, Massachusetts

3. Map showing inundation areas of the 1-percent annual exceedance probability discharge at the West Britannia Dam study site, Taunton, Massachusetts...

4. Map showing inundation areas of the 1-percent annual exceedance probability discharge at the Hopewell Mills Dam study site, Taunton, Massachusetts.. 
5. Map showing inundation areas of the 1-percent annual exceedance probability discharge at the Bradford Dam study site, Westerly, Rhode Island....

6. Map showing inundation areas of the 1-percent annual exceedance probability discharge at the White Rock Dam study site, Westerly, Rhode Island . .8

7. Map showing inundation areas of the 1-percent annual exceedance probability discharge at the Hyde Pond Dam study site, Mystic, Connecticut .9

8. Map showing inundation areas of the 1-percent annual exceedance probability discharge at the Pond Lily Dam study site, New Haven, Connecticut. 10

9. Map showing inundation areas of the 1-percent annual exceedance probability discharge at the Hughesville Dam study site, Warren Glen, New Jersey.

10. Map showing inundation areas of the 1-percent annual exceedance probability discharge at the Wreck Pond Brook Outfall study site, Spring Lake, New Jersey .........12

11. Profile plots of the 1-percent annual exceedance probability discharge and April mean monthly discharge water-surface elevation at the Hyde Pond study reach in Mystic, Connecticut.

\section{Tables}

1. Flood discharges of the 50-, 20-, 10-, 4-, 2-, 1-, 0.5-, and 0.2-percent annual exceedance probabilities at streamgages and dam-removal and culvert-retrofit study sites in Massachusetts, Rhode Island, Connecticut, and New Jersey.....

2. Monthly discharge statistics computed at streamgages and dam-removal study sites in Massachusetts, Rhode Island, Connecticut, and New Jersey.

3. Median discharge statistics for selected months computed at Pond Lily Dam site on West River in New Haven, Connecticut.

4. Water-surface elevations at the dam approach cross section at the Whittenton Dam study site in Taunton, Massachusetts

5. Water-surface elevations at the approach to the dam and canal at the West Britannia Dam study site in Taunton, Massachusetts.

6. Water-surface elevations at the dam approach cross section at the Hopewell Dam study site in Taunton, Massachusetts

7. Water-surface elevations at the dam approach cross section at the Bradford Dam study site in Westerly, Rhode Island

8. Water-surface elevations at the approach to the dam and canal at the White Rock Dam study site in Westerly, Rhode Island

9. Water-surface elevations at the dam approach cross section at the Hyde Pond Dam study site in Mystic, Connecticut.

10. Water-surface elevations at the dam approach cross section at the Pond Lily Dam study site in New Haven, Connecticut.

11. Water-surface elevations at the dam approach cross section at the Hughesville Dam study site in Warren Glen, New Jersey.

12. Water-surface elevations at the approach cross section to the outfall at the Wreck Pond Brook Outfall study site in Spring Lake, New Jersey

13. Water velocities from the two-dimensional models at the dam approach and where the dam was once located at the Whittenton Dam study site in Taunton, Massachusetts. 
14. Water velocities from the two-dimensional models at the approach to the dam and canal and where the dam was once located at the West Britannia Dam study site in Taunton, Massachusetts.

15. Water velocities from the two-dimensional models at the dam approach and where the dam was once located at the Hopewell Dam study site in Taunton, Massachusetts.

16. Water velocities from the two-dimensional models at the dam approach and where the dam was once located at the Bradford Dam study site in Westerly, Rhode Island

17. Water velocities from the two-dimensional models at the approach to the dam and canal and where the dam was once located at the White Rock Dam study site in Westerly, Rhode Island

18. Water velocities from the two-dimensional models at the dam approach and where the dam was once located at the Hyde Pond Dam study site in Mystic, Connecticut.

19. Water velocities from the two-dimensional models at the dam approach and where the dam was once located at the Pond Lily Dam study site in New Haven, Connecticut.

20. Water velocities from the two-dimensional models at the dam approach and where the dam was once located at the Hughesville Dam study site in Warren Glen, New Jersey

21. Water velocities from the two-dimensional models at the outfall approach and culverts at the Wreck Pond Brook Outfall study site in Spring Lake, New Jersey .........32

22. Fish passage criteria applied to study sites and results, for study reaches in Massachusetts, Rhode Island, Connecticut, and New Jersey.

\section{Conversion Factors}

U.S. customary units to International System of Units

\begin{tabular}{lcl}
\hline \multicolumn{1}{c}{ Multiply } & By & \multicolumn{1}{c}{ To obtain } \\
\hline foot $(\mathrm{ft})$ & Length & \\
mile $(\mathrm{mi})$ & 0.3048 & meter $(\mathrm{m})$ \\
\hline & 1.609 & kilometer $(\mathrm{km})$ \\
\hline acre & Area & \\
square mile $\left(\mathrm{mi}^{2}\right)$ & 0.4047 & hectare $(\mathrm{ha})$ \\
\hline & 2.590 & square kilometer $\left(\mathrm{km}^{2}\right)$ \\
\hline foot per second $(\mathrm{ft} / \mathrm{s})$ & Flow rate & \\
cubic foot per second $(\mathrm{ft} 3 / \mathrm{s})$ & 0.3048 & meter per second $(\mathrm{m} / \mathrm{s})$ \\
\hline
\end{tabular}




\section{Datum}

Vertical coordinate information is referenced to the North American Vertical Datum of 1988 (NAVD 88).

Horizontal coordinate information is referenced to the North American Datum of 1983 (NAD 83).

Elevation, as used in this report, refers to distance above the vertical datum.

\section{Abbreviations}

$\begin{array}{ll}\text { AEP } & \text { annual exceedance probability } \\ \text { CONED } & \text { Coastal National Elevation Database } \\ \text { DEM } & \text { digital elevation model } \\ \text { FWS } & \text { U.S. Fish and Wildlife Service } \\ \text { HEC-RAS } & \text { Hydrologic Engineering Center's River Analysis System } \\ \text { lidar } & \text { light detection and ranging } \\ \text { MOVE.1 } & \text { maintenance of variance extension, type 1 } \\ \text { USGS } & \text { U.S. Geological Survey }\end{array}$




\title{
Hydraulic Modeling at Selected Dam-Removal and Culvert-Retrofit Sites in the Northeastern United States
}

\author{
By Scott A. Olson and Caelan E. Simeone
}

\section{Abstract}

Aquatic connectivity projects, such as removing dams and modifying culverts, have substantial benefits. The restoration of natural flow conditions improves water quality, sediment transport, aquatic and riparian habitat, and fish passage. These projects can also decrease hazards faced by communities by lowering water-surface elevations of flood waters and by removing the risk of dam breaches associated with aging or inadequate infrastructure.

This report documents and provides results of one- and two-dimensional hydraulic models developed for selected rivers and streams in the northeastern United States where a dam was removed or a culvert was retrofitted. The models were developed for conditions before and after the dam removal or culvert modification. The discharges applied in the models included monthly discharges and flood discharges for the annual exceedance probabilities of $50,20,10,4,2,1,0.5$, and 0.2 percent.

This study, by the U.S. Geological Survey in cooperation with the U.S. Fish and Wildlife Service, demonstrates the benefits resulting from dam removal and retrofitting undersized culverts in terms of decreased water-surface elevations during flooding and improved fish passage. The U.S. Army Corps of Engineers Hydrologic Engineering Center's River Analysis System was used to model the sites in one- and twodimensional hydraulics, and decreases in the 1-percent annual exceedance probability discharge water-surface elevation were found at all sites studied. The decreases in water-surface elevation at sites in which the impoundment was removed ranged from 1.3 to 10.4 feet. One site, Bradford Dam in Westerly, Rhode Island, had only a 0.2 -foot decrease, but at that site the dam was replaced by a series of weirs to retain the upstream impoundment and allow fish passage.

Minimal differences were found between the watersurface elevations computed by the one- and two-dimensional models. The two-dimensional models, however, provide the additional benefit of detailed velocity and depth data throughout the channel at a resolution not possible with a onedimensional model. These velocity and depth data allowed for assessment of the suitability for fish passage at the sites. Fish passage was improved at all the sites by removing the dams and retrofitting the culvert. Prolonged swim velocity criteria for selected fish species were maintained throughout three of the nine study sites, and burst swim velocity criteria were met at all study sites.

\section{Introduction}

In the wake of Hurricane Sandy (October-November 2012), the U.S. Department of the Interior provided $\$ 787$ million to fund 160 projects through the Hurricane Sandy Coastal Resiliency Competitive Grant Program that were designed to reduce ecosystem and community vulnerability to threats such as coastal storms, flooding, and erosion. Many of these projects focused on improving or restoring aquatic connectivity (U.S. Fish and Wildlife Service, 2019a).

Aquatic connectivity projects, such as removing dams or improving culvert crossings, have several benefits. Restoration of natural flow conditions in streams improves water quality, sediment transport, aquatic and riparian habitat, and aquatic organism passage. Restoration of a more natural system also improves resilience for surrounding communities by decreasing risks from flood events and removing the risk associated with aging or inadequate infrastructure.

Dams are being removed at an unprecedented rate. Of the approximately 90,000 dams across the United States, about 1,800 dams have been removed (American Rivers, 2021). This investigation by the U.S. Geological Survey, in cooperation with the U.S. Fish and Wildlife Service, aims to demonstrate the benefits of several dam-removal projects in the northeastern United States.

For this investigation, hydraulic models were developed to evaluate velocity and depth suitability for fish passage and to evaluate flood inundation. Both one- and two-dimensional models were developed for scenarios before and after the dam removal or culvert retrofit. Discharges applied in the models include mean or median monthly discharges and flood discharges for the annual exceedance probabilities (AEPs) of 50, $20,10,4,2,1,0.5$, and 0.2 percent.

The hydraulic models were developed for nine aquatic connectivity restoration sites: (1) Whittenton Dam, Mill River, Taunton, Massachusetts; (2) West Britannia Dam, Mill River, Taunton, Mass.; (3) Hopewell Mills Dam, Mill River, Taunton, Mass.; (4) Bradford Dam, Pawcatuck River, 
Westerly, Rhode Island; (5) White Rock Dam, Pawcatuck River, Westerly, R.I.; (6) Hyde Pond Dam, Whitford Brook, Mystic, Connecticut; (7) Pond Lily Dam, West River, New Haven, Conn.; (8) Hughesville Dam, Musconetcong River, Warren Glen, New Jersey; and (9) Wreck Pond Brook Outfall, Wreck Pond Brook, Spring Lake, N.J. (fig. 1).

\section{Purpose and Scope}

The report documents the development and results of one- and two-dimensional hydraulic models generated to evaluate the effects of eight dam removals and one culvert retrofit. The report describes the terrain data, geometric data, and hydrologic data input to the models. Model results are presented for scenarios before and after the dam removal or culvert retrofit. Comparisons of the water-surface elevations and velocities are shown for each scenario over a wide range of discharges. An associated U.S. Geological Survey data release by Simeone and others (2021) has pre-dam-removal geometry data supplied by the U.S. Fish and Wildlife Service (FWS), survey data, photographs, hydrologic data, and the hydraulic models developed for the study sites.

\section{Description of Study Sites}

There are nine study sites from Massachusetts to New Jersey (figs. 1-10). The first three study sites are dam sites on the Mill River in Taunton, Mass. The Mill River flows south through a developed part of Taunton. The dams were originally constructed to provide water and power to industries along the Mill River. The first dam on the Mill River is the Whittenton Dam. It is the upstream-most of the three study sites on the Mill River and has a drainage area of 41.1 square miles. The dam crest was approximately 120 feet long and about 5 feet high near the center of the channel. It had a 46-acre impoundment. It was removed in 2013.

The second dam on the Mill River, the West Britannia Dam, is 3,250 feet downstream from the Whittenton Dam. The drainage area at the dam site is 42.0 square miles. The dam crest was 90 feet wide and about 5 feet high near the center of the channel. The impoundment was about 8 acres. The dam was used to divert water through a factory along the Mill River. The West Britannia Dam was removed in 2018. The third dam on the Mill River, the Hopewell Mills Dam - also known as the State Hospital Dam-is about 2,200 feet downstream from the West Britannia Dam. The drainage area at this dam is 42.3 square miles. The dam crest was about 35 feet in length and roughly 5 feet high near the center of the channel, and the dam impounded about 11 acres of water. It was removed in 2012. The removal of the three dams on the Mill River opened miles of aquatic habitat to migratory species and improved flood resiliency and safety in Taunton, Mass.

The next two dam sites studied were on the Pawcatuck River in Rhode Island. The first was the Bradford Dam in Westerly, R.I. The Bradford Dam's crest was approximately 100 feet in length and about 7 feet high at the center of the channel. The drainage area at the site is 218 square miles. Although the dam site does not impound a reservoir, the river is relatively flat upstream from the dam and has numerous swamps that are affected by backwater from the dam, making the impoundment roughly 600 acres. In 2017, the dam was removed and replaced by a series of eight stone weirs designed for fish passage that cross the river with a low-flow notch in the center of the channel. The replacement of the dam with the weirs did not substantially change the impoundment because the upstream-most weir was at approximately the same elevation as the preexisting dam crest.

The second dam site studied on the Pawcatuck River was the White Rock Dam in Westerly, R.I. The White Rock Dam site has a drainage area of 292 square miles. The crest of the dam was 120 feet long and 8 feet high near the center of the channel. It was used to divert water down a canal to a factory. Although the dam did not impound a reservoir, approximately 33 acres of backwater was caused by the dam during normal flow conditions. The dam was removed in 2015, and the canal that conveyed water diverted to the factory was filled in.

Two small stream dam sites were studied in Connecticut. The first, Hyde Pond Dam, is the site of a 2016 dam removal in Mystic, Conn. This dam site is on Whitford Brook and has a drainage area of 15.0 square miles. The dam crest was approximately 50 feet long and 6 feet high at the center of the channel. The impoundment above the dam was about 12 acres. The second is Pond Lily Dam on the West River in New Haven, Conn. It was also removed in 2016. The drainage area of the West River at the Pond Lily Dam is 17.1 square miles. The dam crest was about 200 feet long and 6 feet high at the center of the channel. The impoundment upstream from the dam was about 8 acres. Both dams were removed to eliminate the threat of a dam breach and to open habitat for migratory species of fish.

There were two study sites in New Jersey. One was a dam-removal site, and one was a culvert-retrofit site. The dam-removal study site was the Hughesville Dam site on the Musconetcong River in Warren Glen, N.J. The Musconetcong River has a drainage area of 148 square miles at the study site. The dam crest was 147 feet long and 14 feet high at the center of the channel. The dam was removed in 2016. The dam was considered a run-of-the-river dam site and to have no impoundment.

The culvert-retrofit site was at the Wreck Pond Brook Outfall in Spring Lake, N.J. The site has a drainage area of 12.7 square miles. The outfall structure at the outlet of Wreck Pond Brook is meant to regulate the tidal flows at the mouth of the brook to prevent inland flooding from tidal surge. The original outfall structure is a 795-foot-long, 7-foot-diameter circular conduit with a gate structure at its upstream end. The conduit passes under the beach and empties into the ocean. The site was retrofit in 2016 with an additional 600 -footlong, 8-foot-by-5-foot rectangular conduit with a sluice gate at its upstream end. The additional conduit increased aquatic connectivity and increased discharge capacity from Wreck Pond Brook. 


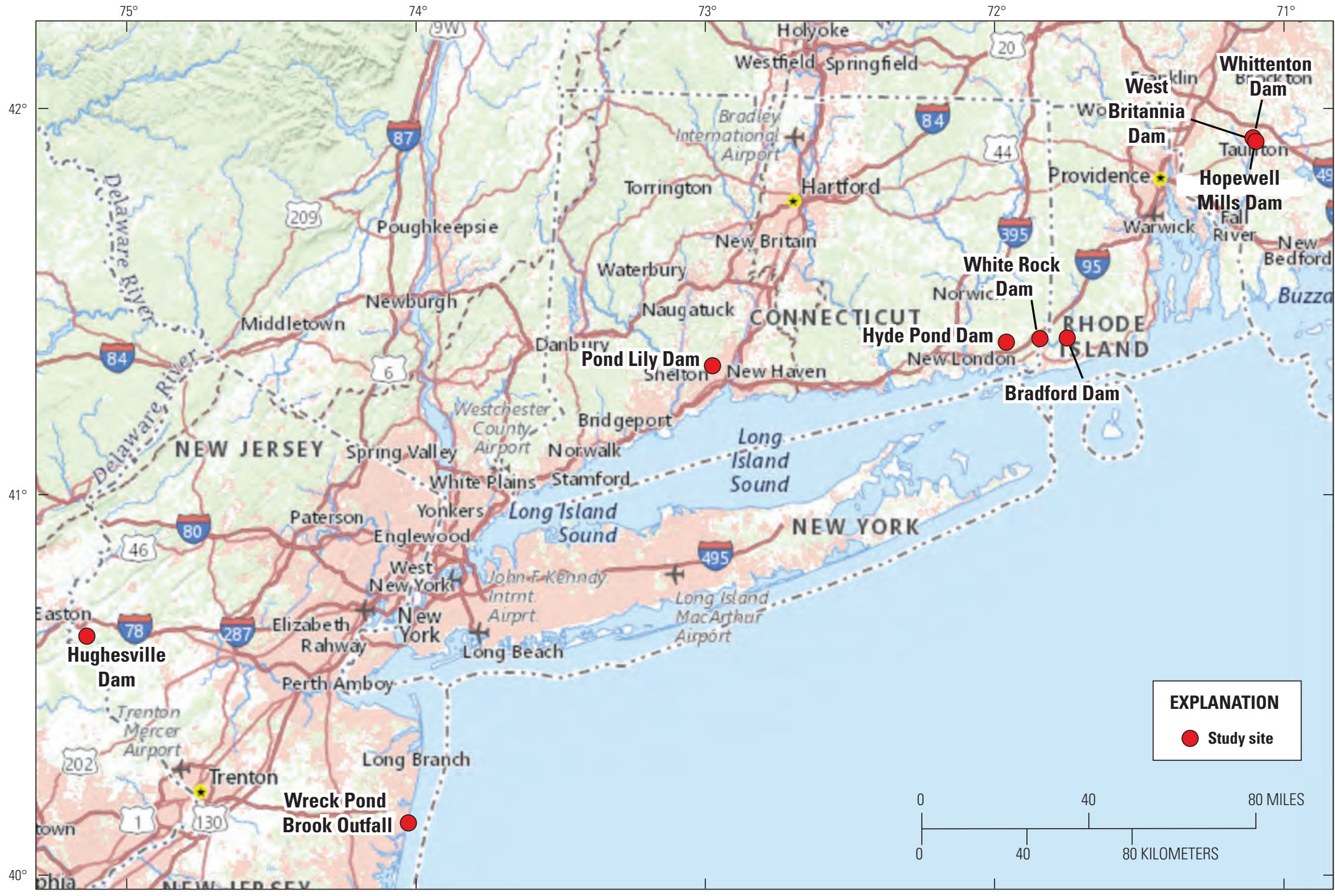

Dhla 1 Min irncrv

The National Map digital data, 2020

Figure 1. Locations of the nine study sites in Massachusetts, Rhode Island, Connecticut, and New Jersey. 


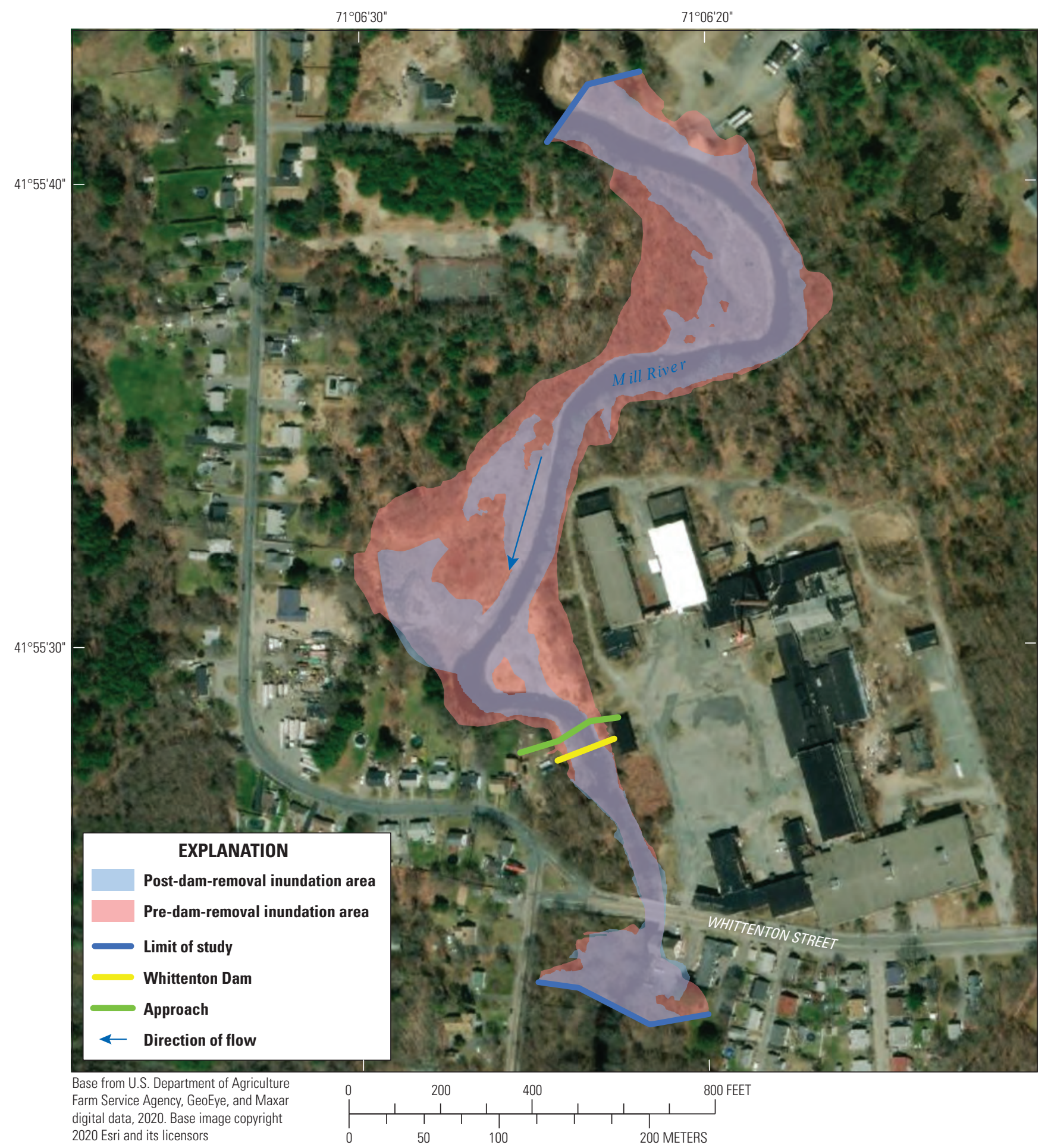

Figure 2. Inundation areas of the 1-percent annual exceedance probability discharge at the Whittenton Dam study site, Taunton, Massachusetts. 


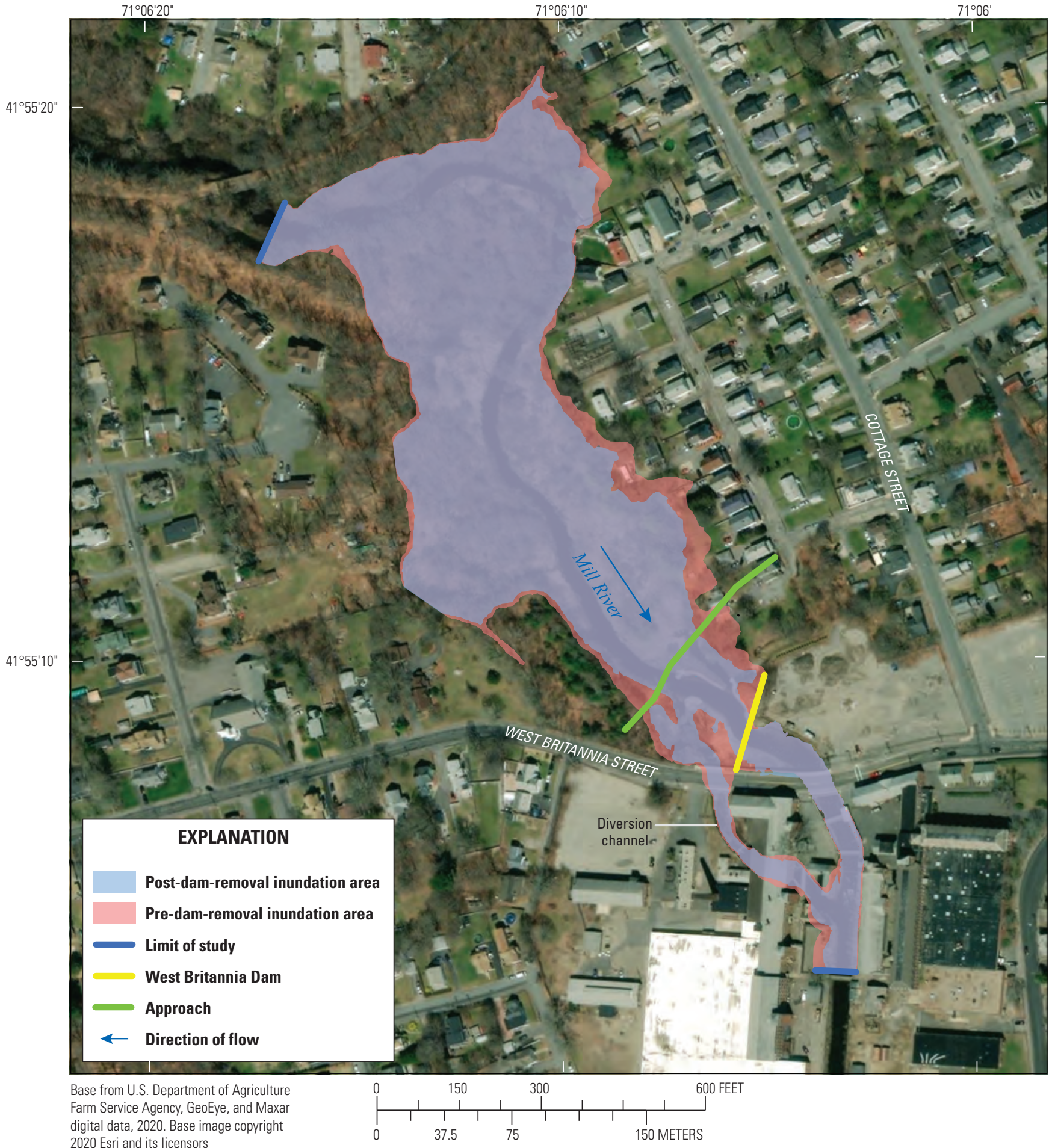

Figure 3. Inundation areas of the 1-percent annual exceedance probability discharge at the West Britannia Dam study site, Taunton, Massachusetts. 
$71^{\circ} 06^{\prime} 05^{\prime \prime}$

$71^{\circ} 06^{\prime}$

$71^{\circ} 05^{\prime} 55^{\prime \prime}$

$71^{\circ} 5^{\prime} 50^{\prime \prime}$

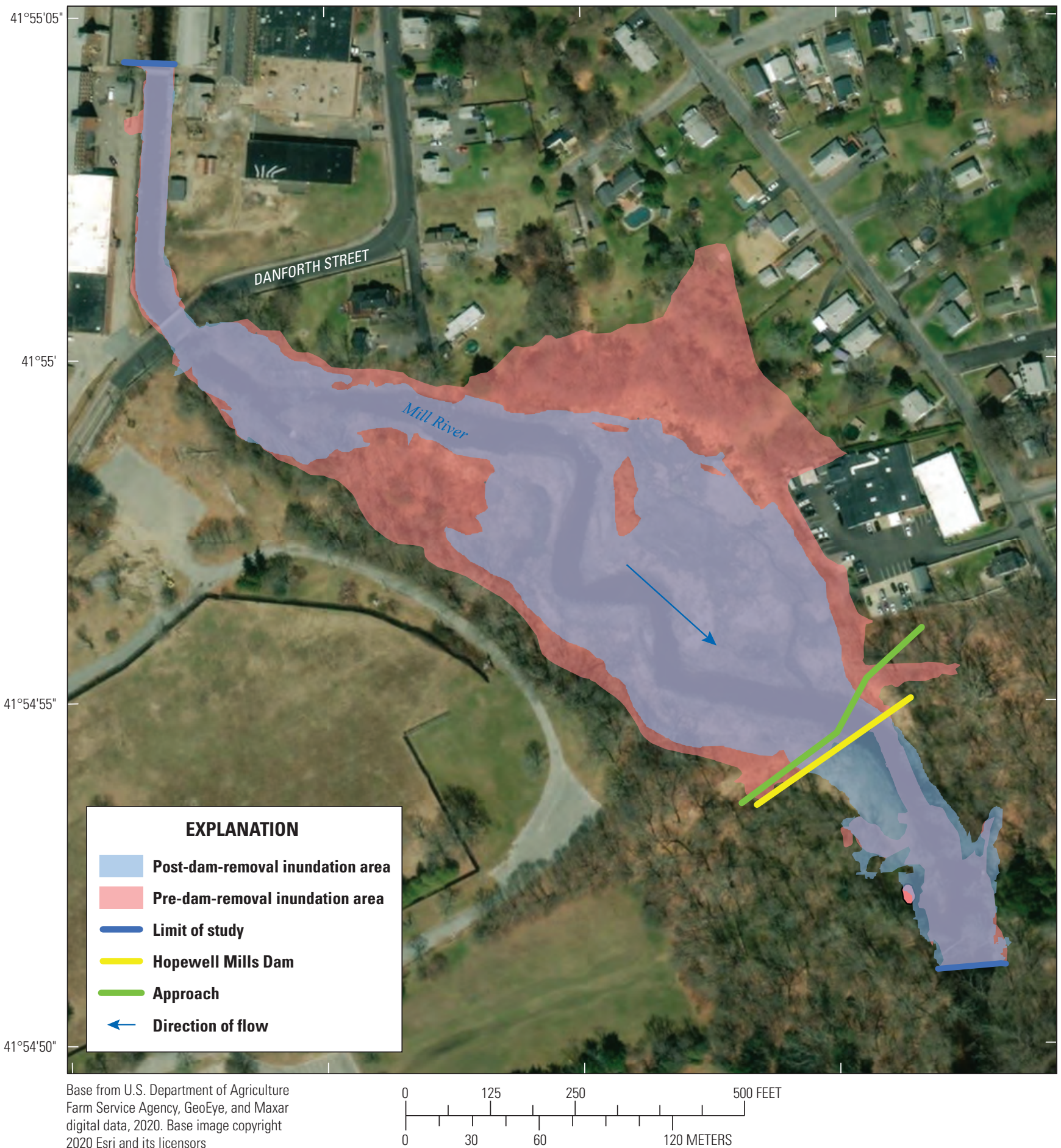

Figure 4. Inundation areas of the 1-percent annual exceedance probability discharge at the Hopewell Mills Dam study site, Taunton, Massachusetts. 


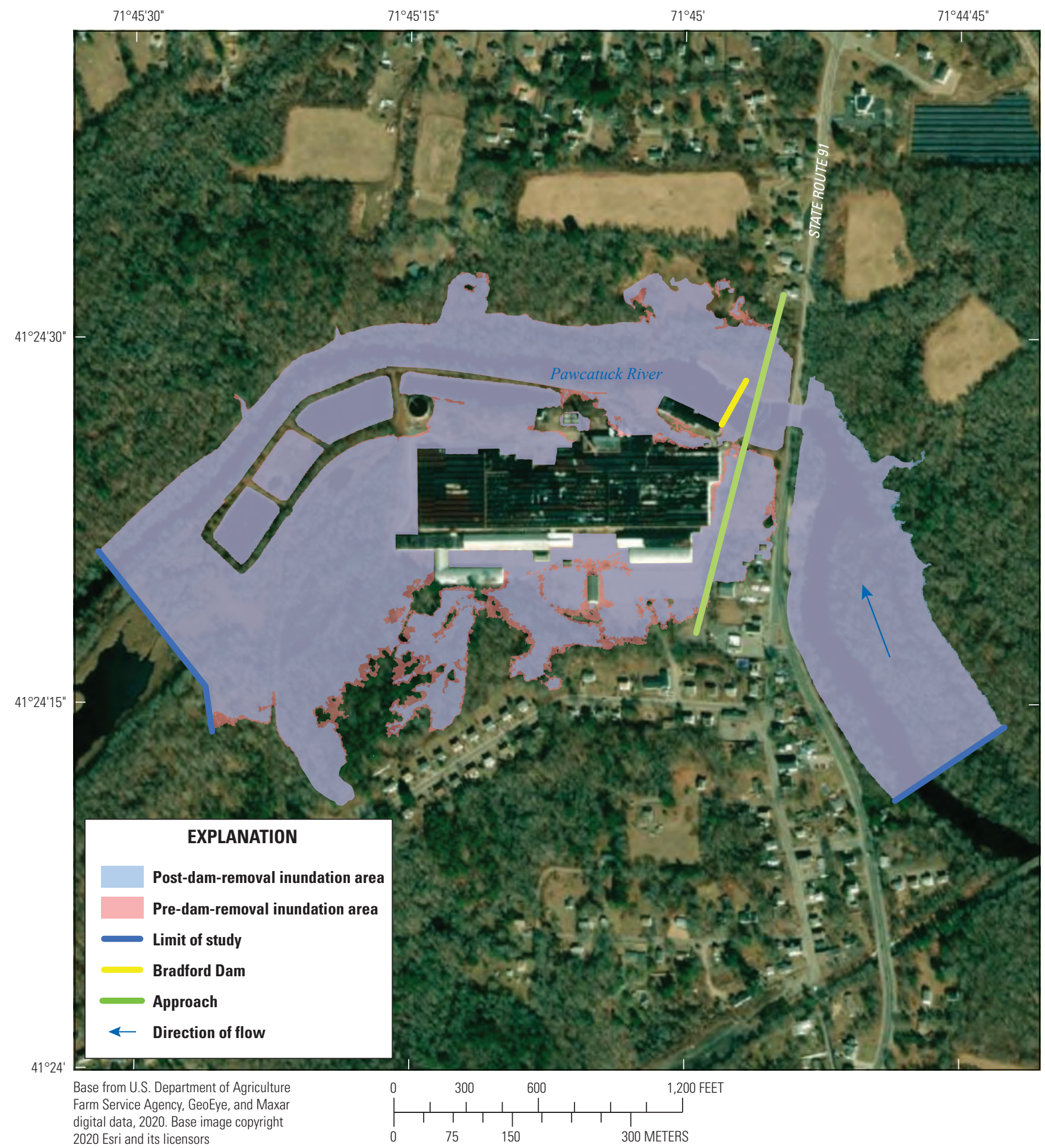

Figure 5. Inundation areas of the 1-percent annual exceedance probability discharge at the Bradford Dam study site, Westerly, Rhode Island. 


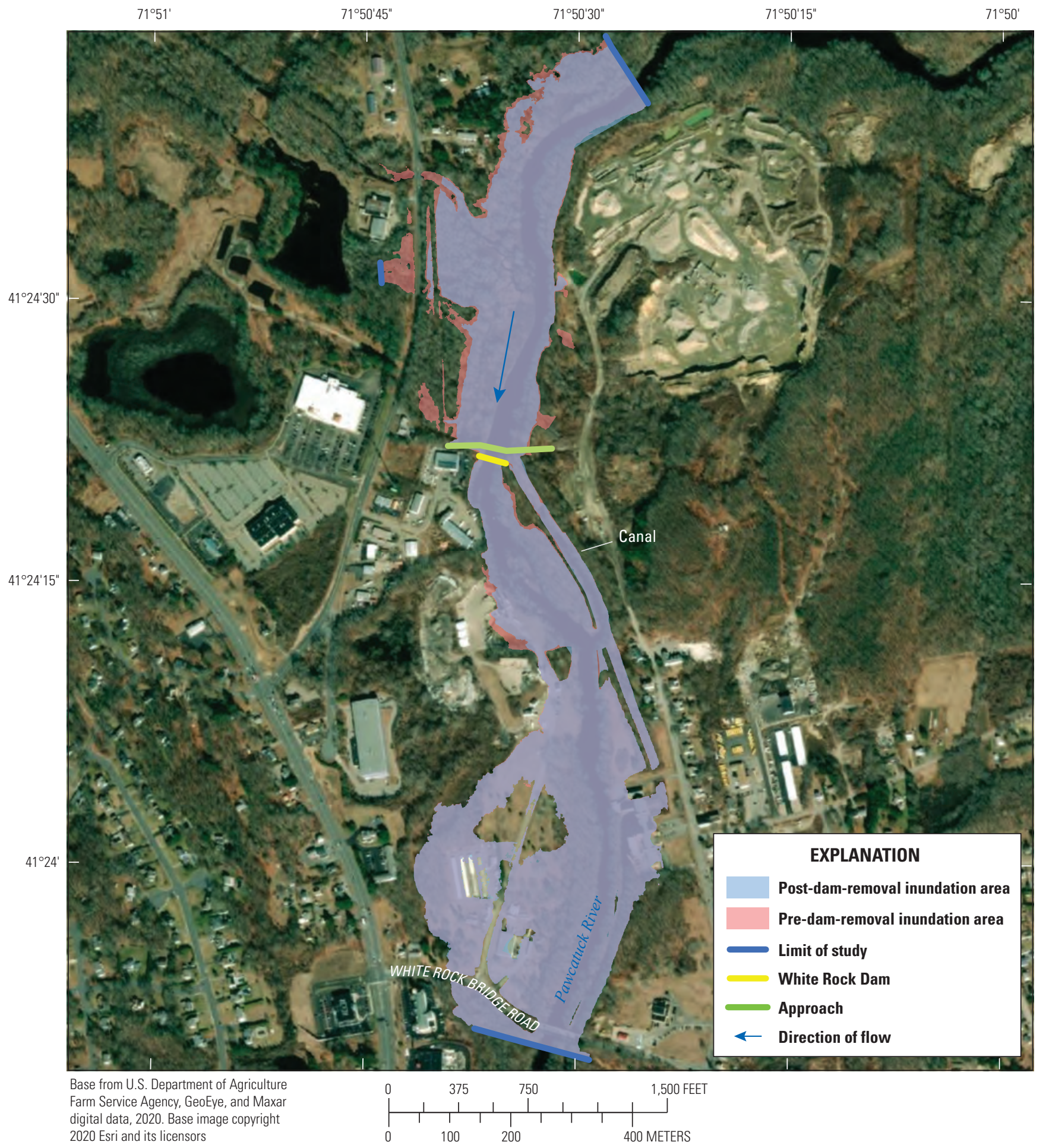

Figure 6. Inundation areas of the 1-percent annual exceedance probability discharge at the White Rock Dam study site, Westerly, Rhode Island. 


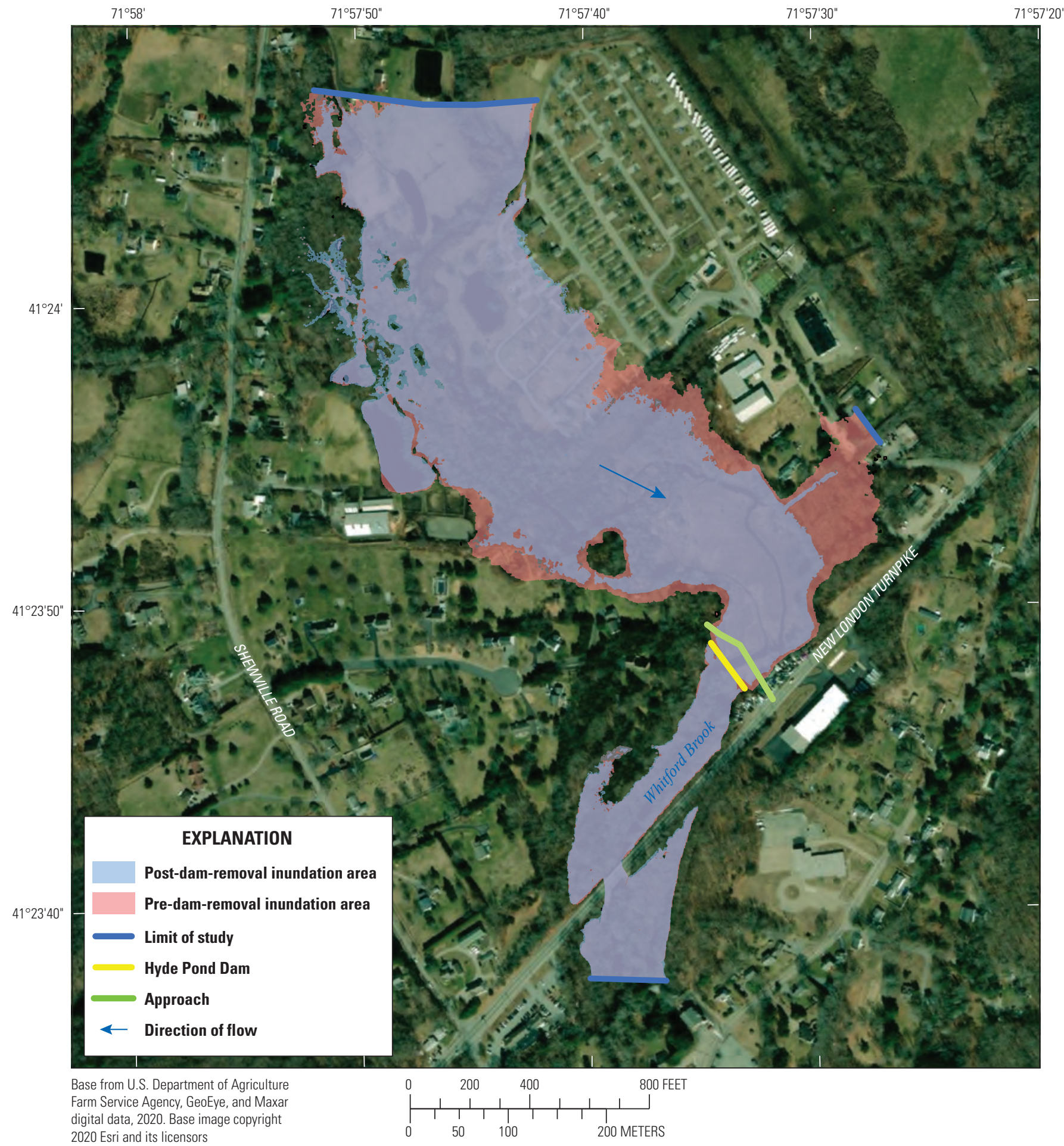

Figure 7. Inundation areas of the 1-percent annual exceedance probability discharge at the Hyde Pond Dam study site, Mystic, Connecticut. 


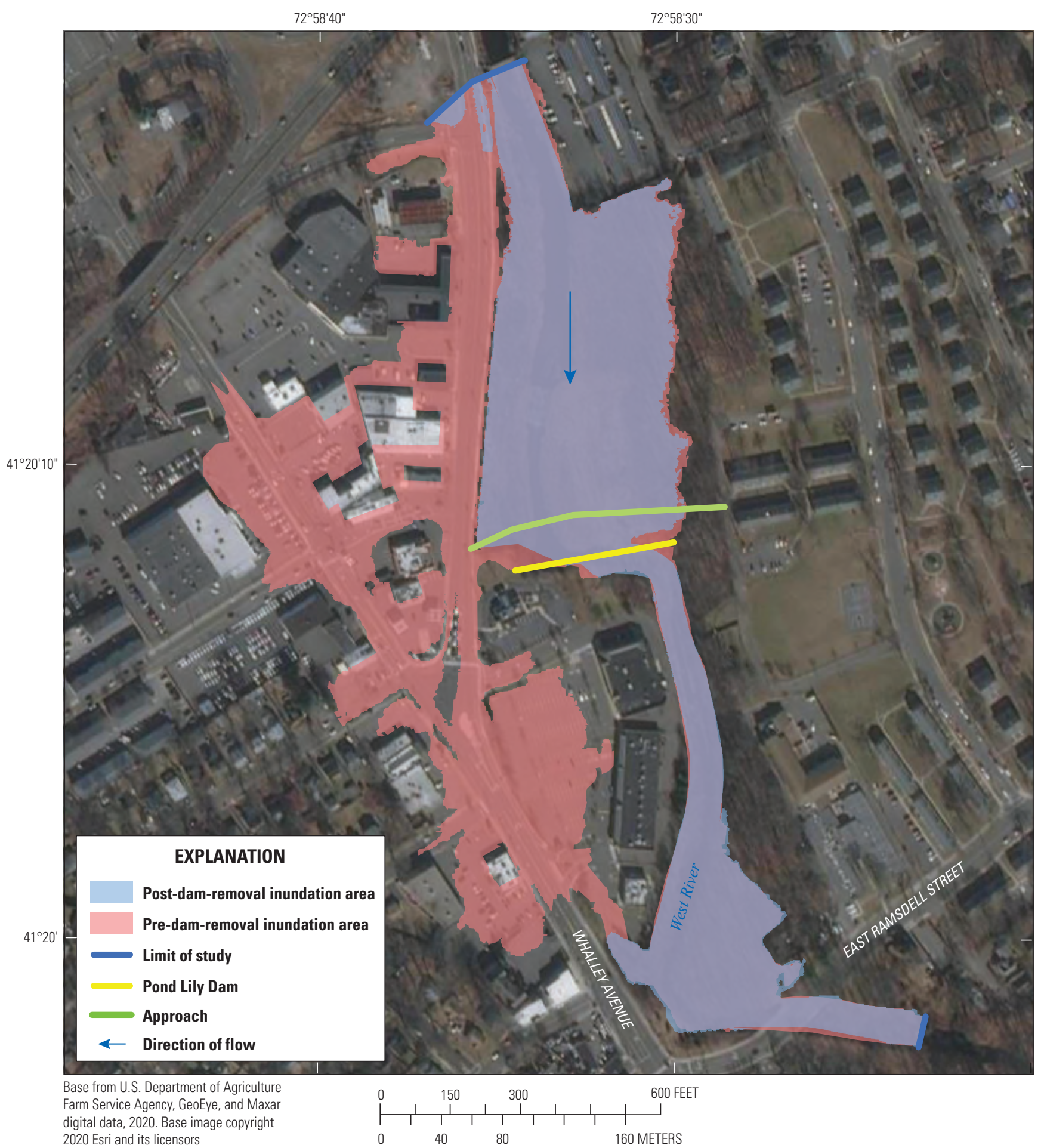

Figure 8. Inundation areas of the 1-percent annual exceedance probability discharge at the Pond Lily Dam study site, New Haven, Connecticut. 


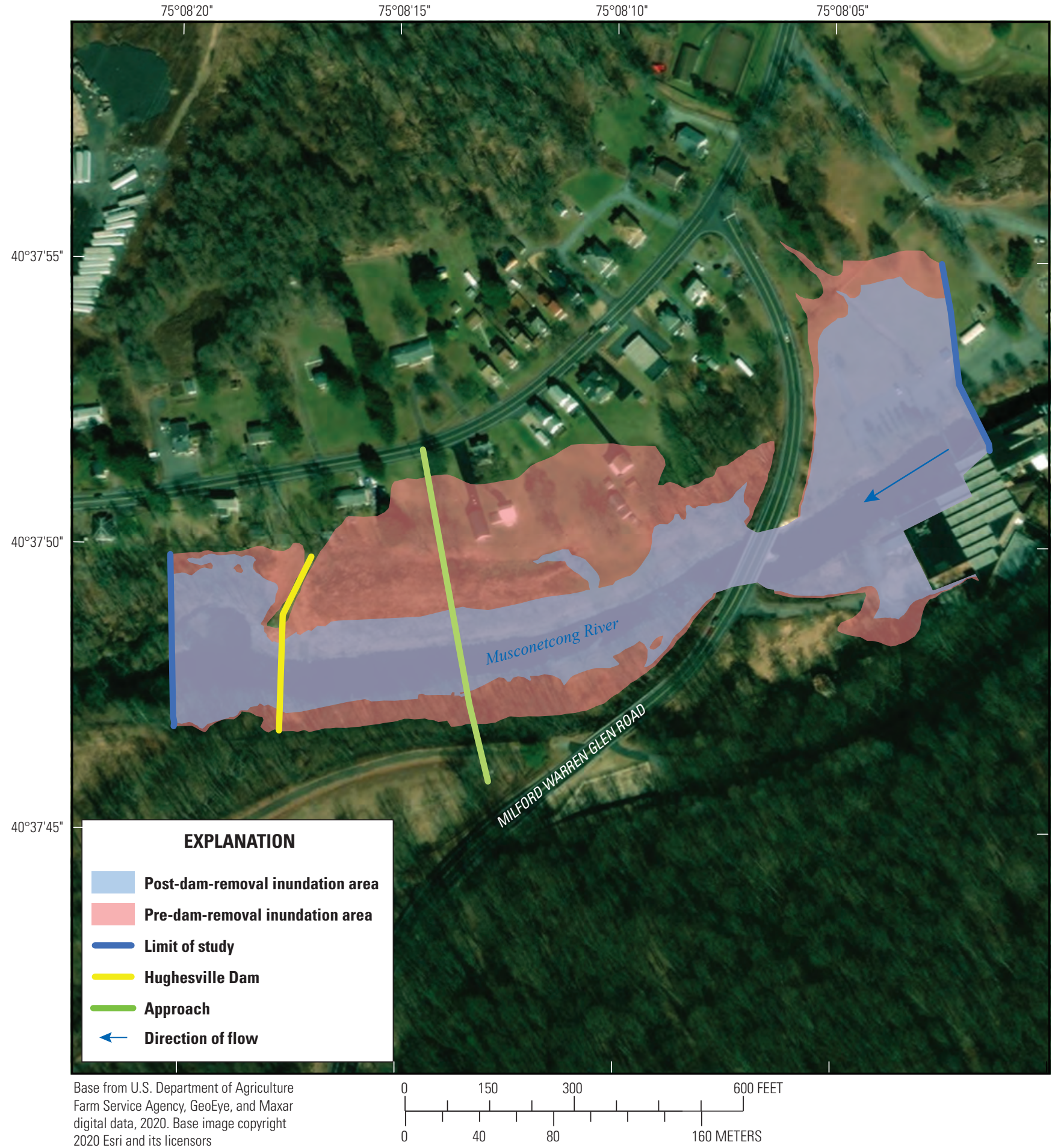

Figure 9. Inundation areas of the 1-percent annual exceedance probability discharge at the Hughesville Dam study site, Warren Glen, New Jersey. 


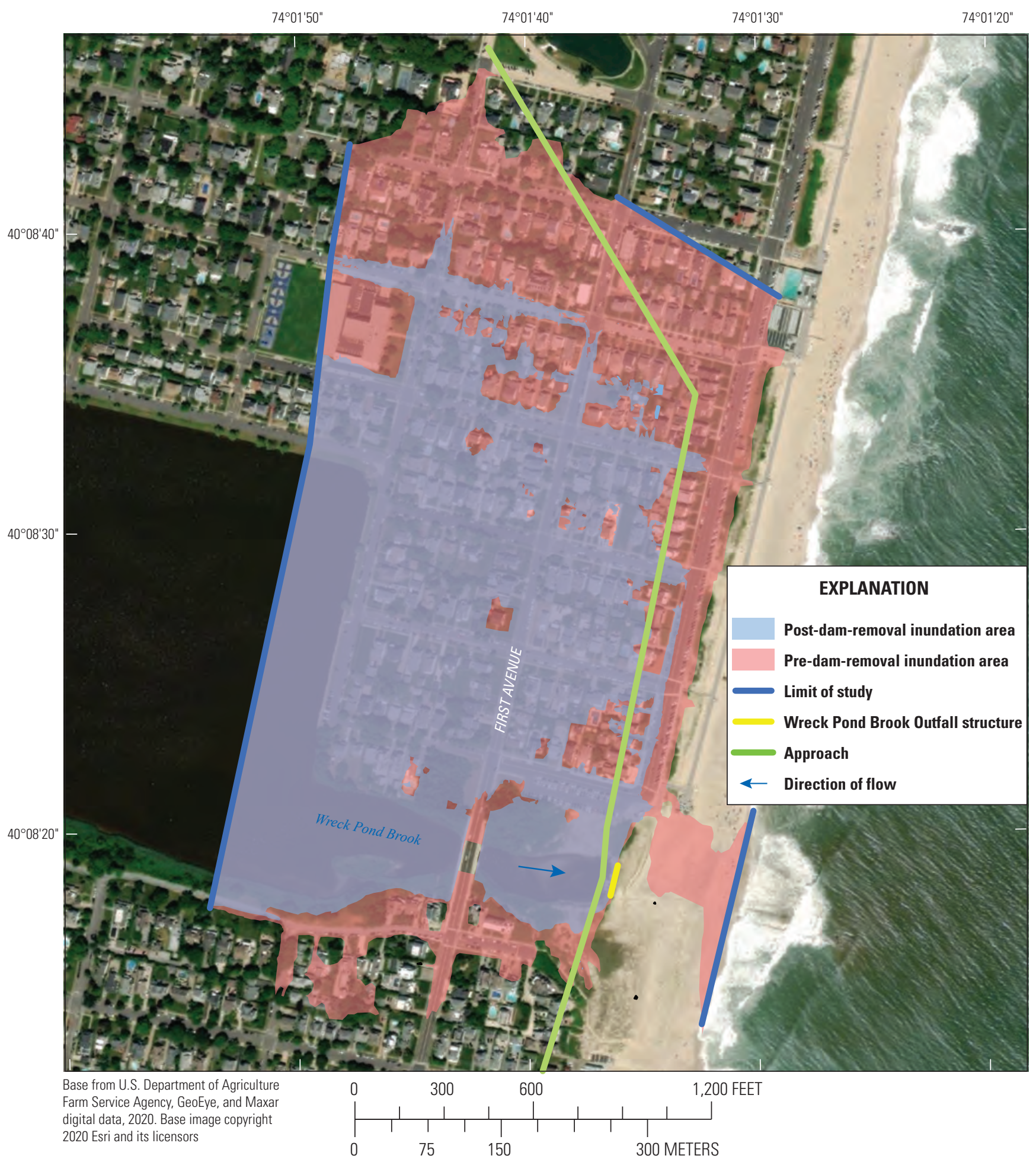

Figure 10. Inundation areas of the 1-percent annual exceedance probability discharge at the Wreck Pond Brook Outfall study site, Spring Lake, New Jersey. 


\section{Development of Hydraulic Models}

Both one- and two-dimensional hydraulic models for the study sites were developed by using the U.S. Army Corps of Engineers Hydrologic Engineering Center's River Analysis System (HEC-RAS), version 5.0.6 (U.S. Army Corps of Engineers, 2016). The hydraulic models were developed for conditions before and after dam removal or culvert retrofit. Geometry data of the dam or culvert and a digital elevation model (DEM) of the terrain incorporating the channel bathymetry and surrounding topography, before and after the dam removal or culvert retrofit, were needed for model input. The models were run using the mean or median monthly discharges and the flood discharges for the AEPs of 50, 20, 10, 4, $2,1,0.5$, and 0.2 percent.

\section{Data Used to Develop Models}

Available data were used to develop the hydraulic models for conditions before dam removal or culvert retrofit at each site. The available data included topography, bathymetry, and structural geometry data. The topography datasets used for the digital elevation models (DEMs) in the hydraulic models were obtained from preexisting sources of light detection and ranging (lidar) or DEM data. The FWS provided much of the preremoval data. These were data that had been used in the planning of the dam removals and culvert retrofit, including DEMs, survey data, existing hydraulic models, and site plans with structural and topographic information. Often the provided data were merged with publically available elevation datasets to produce the final terrain dataset used in the models.

To develop the hydraulic models at the sites for conditions after dam removal or culvert retrofit, the latest lidar data were merged with field survey data. The sites were surveyed between June 2018 and September 2019 during periods of low flow. Pre-dam-removal geometry data supplied by the FWS, survey data, photographs, hydrologic data, and the hydraulic models of the study sites are available as a U.S. Geological Survey (USGS) data release by Simeone and others (2021). The following subsections describe the data used to develop the models for each study site.

\section{Whittenton Dam}

The FWS provided a DEM developed by Inter-Fluve engineering firm for pre-dam-removal conditions. This pre-dam-removal DEM contained bathymetric data. For the post-dam-removal conditions, a new base DEM was developed by using the DEM from the Coastal National Elevation Database (CONED) Project (U.S. Geological Survey, 2016). A new bathymetric DEM was generated from newly surveyed bathymetric points by using ArcGIS Pro (Esri, 2020) and GeoHECRAS (CivilGEO, Inc., 2020) software. The new bathymetric DEM was merged into the base DEM by using ArcGIS Pro.
The FWS also provided a HEC-RAS model developed by Inter-Fluve engineering firm. The model was a onedimensional hydraulic model that went from just downstream from the Hopewell Mills Dam site to upstream from the impoundment of the Whittenton Dam and included all three study sites on the Mill River. The model, with minor corrections made to bank stations, roughness, and bathymetry, was used for pre-dam-removal conditions. It was also used as the base for the post-dam-removal one-dimensional model, in which newly surveyed bathymetry was applied in the three study reaches.

The pre- and post-dam-removal one-dimensional models were used as the basis for developing the pre- and post-damremoval two-dimensional models. For the two-dimensional modeling, the one-dimensional models were shortened to be specific to the dam sites. At the Whittenton Dam site (fig. 2), the resulting model extended from about 200 feet downstream from the Whittenton Street bridge or about 700 feet downstream from the dam to about 2,200 feet upstream from the dam. Sections were removed near the dam and impoundment and replaced by a two-dimensional mesh generated from the respective pre- or post-dam-removal DEM. The meshes extended from about 250 downstream to 400 feet upstream from the dam location.

\section{West Britannia Dam}

The models for the West Britannia Dam site (fig. 3) were developed in the same way the Whittenton Dam models were developed. For the West Britannia Dam, the models extended from about 500 feet downstream from the dam to about 1,800 feet upstream from the dam location. The twodimensional mesh for the pre-dam-removal model extended from about 100 feet downstream from the dam to about 280 feet upstream from the dam. The two-dimensional mesh for the post-dam-removal model extended from about 100 feet downstream from the dam site to about 430 feet upstream from the dam site.

\section{Hopewell Mills Dam}

The models for the Hopewell Mills Dam site (fig. 4) were developed in the same way the Whittenton Dam models were developed. For the Hopewell Mills Dam, the models extended from about 400 feet downstream from the dam to about 1,750 feet upstream from the dam site. The two-dimensional meshes for the models extended from about 200 feet downstream from the dam to about 1,280 feet upstream from the dam.

\section{Bradford Dam}

The DEM for the pre-dam-removal model of the Bradford Dam study site reach (fig. 5) was developed from several sources. The base dataset was the DEM from lidar 
data collected in 2011 (Rhode Island Geographic Information System, 2013). Additional data provided by the FWS included bathymetric contours surrounding the dam site and a HEC-RAS hydraulic model of the river reach. These data provided by the FWS were developed by Fuss \& O'Neill engineering consultants before the dam removal. These bathymetric contour data were converted to a DEM by using ArcGIS Pro software. The bathymetry from the hydraulic model's cross sections were converted to a DEM by using tools within HEC-RAS. Another DEM was developed of the buildings in the floodplain. The DEMs of the channel bathymetry, the detailed bathymetry around the dam, and the buildings were then merged into the base DEM to develop the final dataset used in the preremoval hydraulic modeling for this site.

This DEM was then used to develop the one-dimensional and two-dimensional models for preremoval conditions. The models generated for the Bradford Dam site extended from 2,900 feet downstream from the dam location to 2,050 feet upstream. Cross sections were derived from the DEM, which mimicked the sections in the furnished model. The geometry of the removed dam and the bridge 280 feet upstream from the dam (Rhode Island State Route 91) used in the preremoval hydraulic model were gleaned from the furnished HEC-RAS model. For the two-dimensional models, selected cross sections were removed from the one-dimensional model and replaced with a two-dimensional mesh that extended from 2,900 feet downstream from the dam to about 200 upstream from the dam.

The DEM for the conditions after the dam removal was also based upon the 2011 DEM for overbank areas. However, the bathymetry for this DEM was based upon field surveys done for this project. The surveyed bathymetry was converted to a DEM by using tools in HEC-RAS. The cross sections and the two-dimensional mesh for the post-dam-removal models were generated from this DEM. The geometry of the eight weirs that were constructed in place of the dam and the geometry of the bridge were surveyed and used in the post-damremoval models. The extents of the post-dam-removal model and two-dimensional mesh were the same as the extents of the pre-dam-removal models.

\section{White Rock Dam}

The DEM for the preremoval topography of the White Rock Dam study site reach (fig. 6) was developed from several sources. The base dataset was a DEM developed as part of the CONED Project (U.S. Geological Survey, 2016). Additional data provided by the FWS included bathymetric contours below the dam location and a HEC-RAS hydraulic model of the river reach. These data provided by the FWS were developed by Fuss \& O'Neill engineering consultants before the dam removal. The bathymetric data were converted to a DEM by using ArcGIS Pro software. Additional bathymetry from the furnished hydraulic model's cross sections were converted to a DEM by using tools in the GeoHECRAS software. The
DEMs of the channel bathymetry were then merged into the base DEM by using ArcGIS Pro to develop the final dataset used in the preremoval hydraulic modeling.

This DEM was used to develop the one-dimensional and two-dimensional models for preremoval conditions. The models extended from the White Rock Bridge Road, 3,400 feet downstream from the dam, to 3,200 feet upstream from the dam. Cross sections were developed on the basis of the DEM, which mimicked the sections in the provided model. Additional cross sections between the furnished detailed bathymetric data and the downstream bridge (White Rock Bridge Road) were gleaned from the furnished model. The geometry of the dam and the downstream bridge were also taken from the provided HEC-RAS model. The twodimensional model was based on the one-dimensional model. A two-dimensional mesh, which extended from approximately 1,350 feet downstream from the dam to about 450 feet upstream from the dam and incorporated the canal to the east of the river, replaced selected cross sections.

The base DEM for the conditions after the dam removal was also based upon the CONED DEM for overbank areas. However, the bathymetry for this DEM was based upon field surveys done for this project. The surveyed bathymetry extended from about 1,300 feet downstream from the dam site to about 900 feet upstream. The bathymetry was converted to a DEM and merged into the base DEM by using tools in HEC-RAS and ArcGIS Pro. Cross sections and twodimensional mesh for the post-dam-removal models were developed on the basis of this final DEM. The cross sections beyond the surveyed bathymetry and for the bridge (White Rock Bridge Road) at the downstream end of the model were taken from the pre-dam-removal model.

\section{Hyde Pond Dam}

The DEM for the preremoval topography of the Hyde Pond Dam study site (fig. 7) was developed from several sources. The base dataset was a DEM developed as part of the CONED Project (U.S. Geological Survey, 2016). Because of a small gap in the base DEM near the upstream end of the impoundment, data from a 2005 DEM (National Centers for Environmental Information, 2005) were used to fill the gap. Additional data provided by the FWS included bathymetric contour data within the impoundment upstream from the dam site and a HEC-RAS model of the site. These furnished data were developed by Princeton Hydro engineering consultants before the dam removal. The bathymetric contour data in the impoundment were converted to a DEM by using ArcGIS Pro software. Additional bathymetry from the hydraulic model's cross sections was difficult to use because the model was not georeferenced. However, estimates of cross-section locations were made and the bathymetry was converted to a DEM by using tools within HEC-RAS. For 1,100 feet of the upstream end of the study, no pre-dam-removal bathymetric data were available, so a bathymetric DEM of this reach was generated 
by using new survey data collected for this study. The DEMs of the channel bathymetry were merged into the base DEM to develop the final dataset of the pre-dam-removal DEM.

The pre-dam-removal DEM was used to develop the one-dimensional model for pre-dam-removal conditions. The model extended from 1,200 feet downstream from the dam to 3,250 feet upstream. Cross sections were generated by using the pre-dam-removal DEM. Channel elevations were adjusted at some sections on the basis of the furnished model. This was necessary because the furnished model was not georeferenced and channel data in the pre-dam-removal DEM did not match the furnished model in some locations. No adjustments were made to cross sections in the impoundment where the bathymetric contour data were available.

The geometry of the dam for the one-dimensional predam-removal model was taken from the furnished HEC-RAS model. Since the State Route 184 bridge in the furnished HEC-RAS model was of proposed dimensions that had not yet been built, the bridge in the pre-dam-removal model was generated by using new survey data collected for this study.

The pre-dam-removal one-dimensional model was used to develop the two-dimensional hydraulic model. In the twodimensional model, cross-section data from 680 feet downstream from the dam to the upstream end of the study reach were removed and replaced with a two-dimensional mesh. This mesh extended from 680 feet downstream from the dam to 3,250 feet upstream from the dam. The mesh was generated from the pre-dam-removal DEM.

The base DEM for the conditions after the dam removal was based upon the 2016 DEM (Capitol Region Council of Governments, 2017). The bathymetry for this DEM was based upon field surveys done for this project. The surveyed bathymetry was available for the entire study reach from 1,200 feet downstream from the dam to 3,250 feet upstream. The bathymetry was converted to a DEM and merged into the base DEM by using tools in ArcGIS Pro and HEC-RAS. Cross sections and the two-dimensional mesh for the post-dam-removal models were developed on the basis of this final post-damremoval DEM. The geometry of the bridge at the downstream end of the study reach was also from the study's survey data. The post-dam-removal models and two-dimensional mesh had the same areal extent as the pre-dam-removal models and mesh.

\section{Pond Lily Dam}

The DEM for the preremoval conditions of the Pond Lily Dam study site reach (fig. 8) was developed from several sources. The base dataset was the lidar data collected in 2011 (Federal Emergency Management Agency, 2013). Additional data provided by the FWS included bathymetric elevation data within the reach upstream and downstream from the dam site and a HEC-RAS hydraulic model of the river reach. These furnished data were developed by Stantec engineering consultants before the dam removal. These bathymetric data were converted to a DEM by using ArcGIS Pro software (Esri,
2020). The additional bathymetry from the hydraulic model's cross sections were converted to a DEM by using tools within HEC-RAS. Another DEM was developed of the buildings in the floodplain. The DEMs of the channel bathymetry, the detailed bathymetry around the dam, and the buildings were then merged into the base DEM to develop the final dataset of the pre-dam-removal DEM.

The pre-dam-removal DEM was used to develop the one-dimensional and two-dimensional models for pre-damremoval conditions. The models extended from 1,600 feet downstream from the dam to 1,100 feet upstream. Cross sections were generated on the basis of the DEM, which mimicked the sections in the provided model. The geometry of the dam and the bridge (East Ramsdell Street) at the downstream end of the study reach were gleaned from the provided HEC-RAS model. The two-dimensional mesh generated from the pre-dam-removal DEM extended from approximately 1,150 feet downstream from the dam to about 1,100 feet upstream from the dam.

The base DEM for the conditions after the dam removal was based upon the 2016 DEM (Capitol Region Council of Governments, 2017) for overbank areas. The bathymetry for the reach was based upon field surveys done for this project. The surveyed bathymetry went from 450 feet downstream from the dam location to 1,100 feet upstream. Downstream from the surveyed bathymetry, additional bathymetric data from the furnished pre-dam-removal model were used. The bathymetry was converted to a DEM and merged with the DEM of buildings into base DEM by using tools in ArcGIS Pro and HEC-RAS. Cross sections and the two-dimensional mesh for the post-dam-removal models were developed on the basis of this final DEM. The geometry of the bridge at the downstream end of the study reach was taken from the pre-dam-removal model. The post-dam-removal models and two-dimensional mesh had the same areal extent as the predam-removal models and mesh.

\section{Hughesville Dam}

The FWS provided topographic and bathymetric contour data for the Hughesville Dam study site (fig. 9). The FWS also provided a HEC-RAS one-dimensional hydraulic model of the river reach. The furnished data were developed by Princeton Hydro engineering consultants before the dam removal. The topographic and bathymetric contour data were merged and converted to a DEM by using ArcGIS Pro software. Downstream from the part of the site for which bathymetric contour data were provided, additional bathymetry from the furnished hydraulic model's cross sections were converted to a DEM by using tools within GeoHECRAS software. Another DEM was generated of the buildings in the floodplain and of the bridge abutments of the Milford Warren Glen Road bridge. The DEMs were then merged to develop the final dataset of the pre-dam-removal DEM. 
The one-dimensional and two-dimensional pre-damremoval models were based on this pre-dam-removal DEM. Cross sections for the one-dimensional model and the mesh for the two-dimensional model were generated from this DEM. The dam geometry used in both the one- and twodimensional models was taken from the furnished model. The bridge geometry used in the one-dimensional model was taken from the newly surveyed data collected for this study. Both the one-dimensional model and the two-dimensional mesh extended from about 280 feet downstream from the dam to 1,380 feet upstream from the dam. Since the DEM included the bridge abutments, the two-dimensional mesh used in the two-dimensional model extended through the bridge. Modeling the reach with this mesh was viable because the water surface does not reach the deck of this bridge.

To develop the post-dam-removal DEM, the new bathymetry surveyed as part of this study was converted to a DEM by using tools in HEC-RAS. This new bathymetric DEM was then merged with the pre-dam-removal DEM, replacing the pre-dam-removal bathymetry. The post-dam-removal one-dimensional and two-dimensional hydraulic models were then developed on the basis of the post-dam-removal DEM by using the same procedures and extents as used for the predam-removal hydraulic models.

\section{Wreck Pond Brook Outfall}

The DEM for the pre-culvert-retrofit conditions of the Wreck Pond Brook Outfall site (fig. 10) was developed from several sources. The base dataset was the DEM from lidar data collected in 2011 (U.S. Geological Survey, 2012). A DEM of bathymetry was generated from a georeferenced 2014 bathymetric map of Wreck Pond and Wreck Pond Brook (Najarian Associates and Leon S. Avakian, Inc., 2015) by using ArcGIS Pro. A DEM of the First Avenue bridge abutments (about 475 feet upstream from the outfall structure) was generated to facilitate the two-dimensional modeling through the bridge structure. The base DEM, the bathymetric DEM, and the abutment DEM were merged to develop the pre-culvertretrofit DEM.

The pre-culvert-retrofit one-dimensional model was generated from the pre-culvert-retrofit DEM. Cross-section data were generated from this DEM. The geometry of the gate structure on the upstream side of the outfall and the First Avenue bridge geometry in the one-dimensional model were developed from survey data collected for this study. The inverts, length, and diameter of the conduit in the outfall structure were taken from Najarian Associates and Leon S. Avakian, Inc. (2015). The one-dimensional hydraulic model went from the outlet of the outfall to approximately 1,000 feet upstream from the outfall structure. The two-dimensional pre-culvert-retrofit model was generated by using the outfall geometry from the one-dimensional model and a twodimensional mesh generated from the pre-culvert-retrofit DEM extending from 50 feet upstream from the outfall structure to approximately 2,200 feet upstream from the outfall structure.
The base DEM for the conditions after the culvert retrofit was based upon the 2014 DEM (U.S. Geological Survey, 2015). The bathymetry was based upon field surveys done for this project. The surveyed bathymetry went from the outfall structure to roughly 1,000 feet upstream from the outfall structure. The surveyed bathymetry was converted to a DEM and merged with the DEM of the First Avenue bridge into base DEM by using tools in ArcGIS Pro and HEC-RAS to generate the post-culvert-retrofit DEM. The one- and two-dimensional post-culvert-retrofit models were then developed in the same fashion and with the same extents as the pre-culvertretrofit models.

\section{Development of Hydrology}

The models in this study were run by using the mean or median monthly discharges and the flood discharges for the AEPs of 50, 20, 10, 4, 2, 1, 0.5, and 0.2 percent. These statistical flows were obtained from available published sources, computed from available USGS streamgage data, or determined from regression equations by using StreamStats (https://streamstats.usgs.gov/ss/).

For the Mill River, flood discharge hydrology was computed by using available 2006 to 2018 annual peak discharges from the Mill River at Spring Street at Taunton, Mass., streamgage (station identifier 01108410). The annual peak discharges are available from the USGS National Water Information System (U.S. Geological Survey, 2019; https://waterdata.usgs.gov/nwis). The flood discharges for the 50-, 20-, 10-, 4-, 2-, 1-, 0.5-, and 0.2-percent AEPs were computed with the U.S. Geological Survey PeakFQ software (Flynn and others, 2006) by following the guidelines by England and others (2018). The flood discharges were then weighted with the regional regression equations for Massachusetts (Zarriello, 2017) by using techniques described by England and others (2018). Because of the proximity of the streamgage to the three modeled sites on the Mill Riverthe streamgage has a drainage area of 43.5 square miles and the Whittenton Dam Site has a drainage area of 41.1 square miles - the discharges determined at the streamgage were used at all the Mill River dam sites. The resulting flood discharges for the 50-, 20-, 10-, 4-, 2-, 1-, 0.5-, and 0.2-percent AEPs at the Mill River dam sites are shown in table 1.

The mean monthly discharges for the Mill River streamgage were determined from daily mean streamflows from January 2006 to February 2019. A script written for R software (R Core Team, 2017) was used to download and compute the monthly discharges. The R script can be found in the data release (Simeone and others, 2021). Because of the proximity of the Mill River streamgage to the Mill River dam sites, the mean monthly flows determined for the streamgage site were used at all three Mill River dam sites. The resulting mean monthly discharges for the Mill River dam sites are shown in table 2. 
Table 1. Flood discharges of the 50-, 20-, 10-, 4-, 2-, 1-, 0.5-, and 0.2-percent annual exceedance probabilities at streamgages and dam-removal and culvert-retrofit study sites in Massachusetts, Rhode Island, Connecticut, and New Jersey.

$\left[\mathrm{mi}^{2}\right.$, square mile; ft $3 / \mathrm{s}$, cubic foot per second; \%, percent; MA, Massachusetts; RI, Rhode Island; CT, Connecticut; NJ, New Jersey]

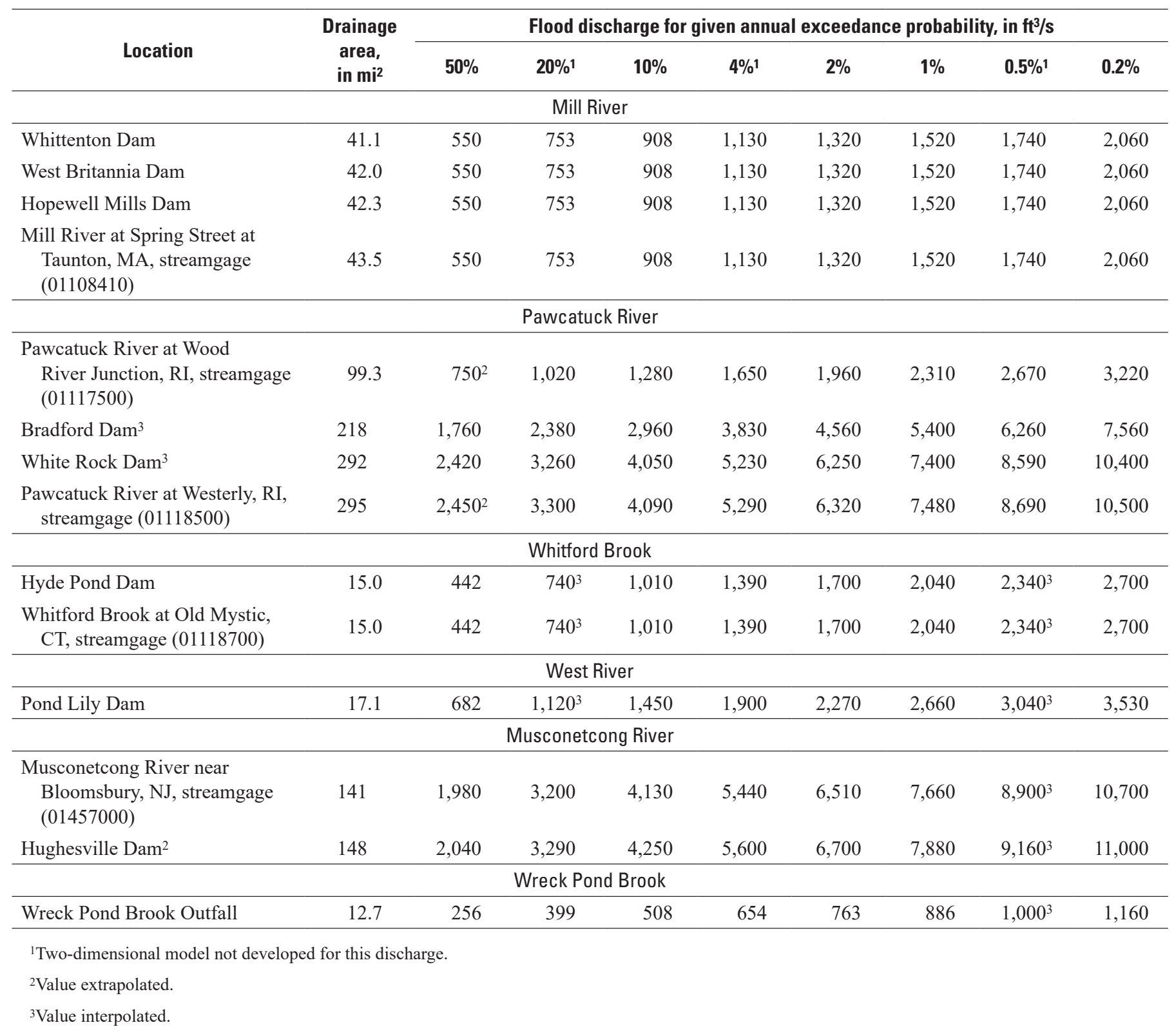

The Bradford Dam site and the White Rock Dam site are both on the Pawcatuck River. The Pawcatuck River has two streamgages-Pawcatuck River at Wood River Junction, R.I. (station identifier: 01117500), and Pawcatuck River at Westerly, R.I. (station identifier: 01118500). The drainage area of the Wood River Junction streamgage is 99.3 square miles, and the drainage area of the Westerly streamgage is 295 square miles. The two dam sites are between the streamgages. The flood discharges for the 50-, 20-, 10-, 4-, 2-, 1-, 0.5-, and 0.2-percent AEPs for the two streamgages were obtained from Zarriello and others (2012). The mean monthly discharges for the Pawcatuck River streamgages were determined from daily mean streamflows from October 1940 to February 2019. A script written for R software (R Core Team, 2017) was used to download and compute the monthly discharges. The R script can be found in the data release (Simeone and others, 2021). The flood discharges and the mean monthly discharges at the Pawcatuck River dam sites were logarithmically interpolated between the two streamgages on the basis of drainage area. The results are shown in tables 1 and 2.

The flood discharges for Whitford Brook at the site of the Hyde Pond Dam were determined by using StreamStats. These discharges from StreamStats were computed on the basis of the regression equations by Ahearn (2004). Mean monthly 
Table 2. Monthly discharge statistics computed at streamgages and dam-removal study sites in Massachusetts, Rhode Island, Connecticut, and New Jersey.

$\left[\mathrm{mi}^{2}\right.$, square mile; fts/s, cubic foot per second; Jan, January; Feb, February; Mar, March; Aug, August; Sept, September; Oct, October; Nov, November; Dec, December; Med, median of the mean monthly discharges; MA, Massachusetts; RI, Rhode Island; CT, Connecticut; NJ, New Jersey; --, not determined]

\begin{tabular}{|c|c|c|c|c|c|c|c|c|c|c|c|c|c|c|}
\hline \multirow{2}{*}{ Location } & \multirow{2}{*}{$\begin{array}{c}\text { Drainage } \\
\text { area, } \\
\text { in } \mathrm{mi}^{2}\end{array}$} & \multicolumn{13}{|c|}{ Mean monthly discharge for given month, in $\mathrm{ft}^{3} / \mathrm{s}$} \\
\hline & & $\operatorname{Jan}^{1}$ & Feb $^{1}$ & Mar & April & May & June $^{1}$ & July' & Aug & Sept & Oct ${ }^{1}$ & Nov $^{1}$ & $\operatorname{Dec}^{1}$ & Med \\
\hline \multicolumn{15}{|c|}{ Mill River } \\
\hline Whittenton Dam & 41.1 & 118 & 124 & 176 & 155 & $87.3^{1}$ & 80.7 & 35.7 & 19.9 & $27.2^{1}$ & 49.6 & 92.2 & 106 & 89.8 \\
\hline West Britannia Dam & 42.0 & 118 & 124 & 176 & 155 & $87.3^{1}$ & 80.7 & 35.7 & 19.9 & $27.2^{1}$ & 49.6 & 92.2 & 106 & 89.8 \\
\hline Hopewell Mills Dam & 42.3 & 118 & 124 & 176 & 155 & $87.3^{1}$ & 80.7 & 35.7 & 19.9 & $27.2^{1}$ & 49.6 & 92.2 & 106 & 89.8 \\
\hline $\begin{array}{l}\text { Mill River at Spring Street at Taunton, } \\
\text { MA, streamgage }(01108410)\end{array}$ & 43.5 & 118 & 124 & 176 & 155 & 87.3 & 80.7 & 35.7 & 19.9 & 27.2 & 49.6 & 92.2 & 106 & -- \\
\hline \multicolumn{15}{|c|}{ Pawcatuck River } \\
\hline $\begin{array}{l}\text { Pawcatuck River at Wood River } \\
\text { Junction, RI, streamgage }(01117500)\end{array}$ & 99.3 & 248 & 271 & 348 & 348 & 254 & 185 & 102 & 82.4 & 77.1 & 92.3 & 149 & 217 & -- \\
\hline Bradford Dam² & 218 & 560 & 599 & 770 & 757 & $541^{1}$ & 389 & 212 & $171^{1}$ & 163 & 204 & 337 & 495 & 442 \\
\hline White Rock Dam² & 292 & 758 & 805 & 1,030 & 1,010 & $716^{1}$ & 513 & 277 & $225^{1}$ & 216 & 274 & 457 & 672 & 592 \\
\hline $\begin{array}{l}\text { Pawcatuck River at Westerly, RI, } \\
\text { streamgage }(01118500)\end{array}$ & 295 & 766 & 813 & 1,040 & 1,020 & 723 & 518 & 280 & 227 & 218 & 277 & 462 & 679 & -- \\
\hline \multicolumn{15}{|c|}{ Whitford Brook } \\
\hline Hyde Pond Dam & 15.0 & 27.6 & 28.1 & 34.6 & 33.7 & $25.1^{1}$ & 17.3 & 7.80 & 6.58 & $6.75^{1}$ & 11.3 & 19.6 & 27.7 & 22.4 \\
\hline $\begin{array}{l}\text { Whitford Brook at Old Mystic, CT, } \\
\text { streamgage (01118700) }\end{array}$ & 15.0 & 27.6 & 28.1 & 34.6 & 33.7 & 25.1 & 17.3 & 7.80 & 6.58 & 6.75 & 11.3 & 19.6 & 27.7 & -- \\
\hline \multicolumn{15}{|c|}{ Musconetcong River } \\
\hline $\begin{array}{l}\text { Musconetcong River near Bloomsbury, } \\
\text { NJ, streamgage (01457000) }\end{array}$ & 141 & 268 & 276 & 349 & 351 & 273 & 205 & 160 & 154 & 165 & 186 & 233 & 282 & -- \\
\hline Hughesville Dam³ & 148 & 281 & 290 & 366 & 368 & 286 & 215 & 168 & 161 & $173^{1}$ & 195 & 244 & 296 & 262 \\
\hline \multicolumn{15}{|c|}{ Wreck Pond Brook } \\
\hline Wreck Pond Brook Outfall & 12.7 & -- & -- & -- & 28.5 & -- & -- & -- & -- & -- & -- & -- & -- & -- \\
\hline
\end{tabular}

${ }^{1}$ Two-dimensional model not developed for this discharge.

${ }^{2}$ Value interpolated.

${ }^{3}$ Value extrapolated. 
discharges for Whitford Brook were taken from Bent and others (2014). These mean monthly discharges were computed for a partial-record streamgage, Whitford Brook at Old Mystic, Conn. (station identifier: 01118700 ), which is approximately 1,000 feet downstream from the Hyde Pond Dam location. The results are shown in tables 1 and 2 .

The flood discharges for West River at the site of the Pond Lily Dam were determined by using StreamStats. These discharges from StreamStats were computed on the basis of the regression equations in Ahearn (2004). There were no available streamgage data or methods for computing mean monthly discharges on the West River. However, Ahearn (2010) published regression equations to estimate the discharge exceeded 50 percent of the time for selected periods. Equating the discharge exceeded 50 percent of the time to the median discharge enabled the use of regression equations to identify median monthly discharges for November, May, and June. Regression equations were also available to identify seasonal median discharges for the periods of December to February, March to April, and July to October. StreamStats was used to compute the monthly discharge statistics for the Pond Lily Dam site. The results are shown in tables 1 and 3.

The Hughesville Dam site is on the Musconetcong River. Flood discharge statistics for the Musconetcong River were available for the Musconetcong River near Bloomsbury, N.J., streamgage (station identifier: 01457000) in Watson and others (2014). The streamgage has a drainage area of 141 square miles. The flood discharges for the 50-, 20-, 10-, 4-, 2-, 1-, $0.5-$, and 0.2-percent AEPs were then transferred downstream to the Hughesville Dam location by using techniques described in Watson and Schopp (2009). The mean monthly discharges for the Musconetcong River streamgage were determined from daily mean streamflows from October 1903 to February 2019. A script written for R software was used to download and compute the monthly discharges. The R script can be found in the data release (Simeone and others, 2021). The mean monthly discharges were transferred downstream to the dam location by using a drainage area ratio of the dam location to the gage location. The results of the flood discharges and mean monthly discharges are shown in tables 1 and 2 , respectively.

The flood discharges for Wreck Pond Brook Outfall site were determined by using StreamStats. These discharges from StreamStats were computed on the basis of the regression equations in Watson and Schopp (2009). The flood discharges modeled on Wreck Pond Brook are shown in table 1. There were no available continuous streamgage data or regression methods for computing mean monthly discharges on the Wreck Pond Brook. However, discharge measurements had been made at a discrete measurement site with 22 discharge measurements, Wreck Pond Brook near Spring Lake, N.J. (station identifier: 01407800). The site had a drainage area of 7.0 square miles. A technique called maintenance of variance extension, type 1 (MOVE.1) (Hirsch, 1979, 1982), was used to correlate those discharge measurements with discharge record from a nearby continuous recording streamgage and use that relationship to estimate discharge statistics at the discrete measurement site.

The nearby continuous streamgage was Manasquan River at Squankum, N.J. (station identifier: 01408000). The Manasquan River streamgage has a drainage area of 44.0 square miles and continuous record from 1931 to present (2020). Baseflow measurements from the Wreck Pond Brook had a correlation coefficient of 0.95 with concurrent daily discharges from the Manasquan River streamgage. The regression relationship between the two sites found with MOVE.1 software developed for New Jersery (Colarullo and others, 2018) was $Q_{\text {Wreck Pond Brook }}=0.3097 Q_{\text {Manasquan River }}{ }^{0.8537}$, where $Q_{\text {Wreck Pond Brook }}$ is the discharge at Wreck Pond Brook discrete measurement site and $Q_{\text {Manasquan River }}$ is the concurrent daily discharge at the Manasquan River continuous streamgage site (Amy McHugh, USGS, written commun., July 2, 2020). The mean monthly April discharge for the Manasquan River streamgage from daily mean streamflows from 1931 to 2019 was determined to be 99.5 cubic feet per second $\left(\mathrm{ft}^{3} / \mathrm{s}\right)$. This mean value was applied to the MOVE.1 regression equation to estimate the mean monthly April discharge for the Wreck Pond Brook discrete measurement site to be $15.7 \mathrm{ft} 3 / \mathrm{s}$. This discharge was then extrapolated to the Wreck Pond Brook Outfall site by using a drainage area ratio. The resulting mean monthly April discharge was estimated to be $28.5 \mathrm{ft}^{3} / \mathrm{s}$.

All the computed discharges were modeled in the one-dimensional model scenarios; however, because of the extensive processing time of the two-dimensional models, the simulated flood discharges were limited to the 50-, 10-, 2-, 1-, and 0.2-percent AEPs, and simulated monthly discharges were limited to the maximum, median, and minimum of the mean or median monthly discharges for the two-dimensional models. To ensure there was a model run that corresponded to the seasonal timing of fish migration, two-dimensional models were run for the mean monthly April discharge at the sites and for the mean monthly May discharge at the Hughesville Dam site.

Table 3. Median discharge statistics for selected months computed at Pond Lily Dam site on West River in New Haven, Connecticut.

$\left[\mathrm{mi}^{2}\right.$, square mile; $\mathrm{ft}^{3} / \mathrm{s}$, cubic foot per second]

\begin{tabular}{|c|c|c|c|c|c|c|c|c|}
\hline \multirow[b]{2}{*}{ Location } & \multirow{2}{*}{$\begin{array}{c}\text { Drainage } \\
\text { area, } \\
\text { in } \text { mi }^{2}\end{array}$} & \multicolumn{6}{|c|}{ Median seasonal or monthly discharge for given month(s), in $\mathrm{ft}^{3} / \mathrm{s}$} & \multirow{2}{*}{$\begin{array}{c}\text { Median, } \\
\text { in } \mathrm{ft}^{3} / \mathrm{s}\end{array}$} \\
\hline & & $\begin{array}{c}\text { December to } \\
\text { February }\end{array}$ & $\begin{array}{c}\text { March to } \\
\text { April }\end{array}$ & May & June & $\begin{array}{l}\text { July to } \\
\text { October }\end{array}$ & November & \\
\hline
\end{tabular}

${ }^{1}$ Two-dimensional model not developed for this discharge. 


\section{Model Execution}

HEC-RAS was used for the one-dimensional and twodimensional hydraulic modeling of the study sites. The following sections provide information critical to the results of the one-dimensional and two-dimensional models.

\section{One-Dimensional Hydraulic Models}

One of the most important values in a subcritical hydraulic model is the downstream boundary condition. Although the downstream boundary is important, the downstream boundary was far enough downstream, and downstream from any structures, that the model at the dam location would not be sensitive to variability in the boundary condition. Unless otherwise noted, normal depth was used as the downstream boundary condition. Normal depth requires a representative slope of the energy grade line at the downstream-most cross section. This representative slope is approximated by using the channel slope at the cross section. The Mill River onedimensional model extended from just downstream from the Hopewell Mills Dam to the upstream end of the Whittenton Dam impoundment. The normal-depth slope of 0.0025 , used as the downstream boundary condition in the pre-dam-removal model, was taken from the energy grade line at the corresponding cross section of the model provided by FWS. The slope used in the post-dam-removal model was 0.007 and was estimated from the channel-bed slope in the same location.

A notable feature of the Mill River model is the split flow at the West Britannia Dam location (fig. 3). This dam created backwater that diverted some of the river water to a diversion channel through a mill. In the pre-dam-removal model, the three simulations with the lowest discharges - the July, August, and September mean monthly discharges - resulted in all the water going through the diversion channel and no water going over the dam. There was split flow for all the other discharges. In the post-dam-removal model, the models only diverted water above the 50-percent AEP discharge $\left(550 \mathrm{ft}^{3} / \mathrm{s}\right)$. At and below the 50-percent AEP discharge, all discharge stayed in the main channel where the dam had once been.

A software glitch was discovered in the post-damremoval model at discharges lower than the February mean monthly discharge, $124 \mathrm{ft}^{3} / \mathrm{s}$. Below this discharge, the computed water-surface-elevation profiles were physically impossible and crossed over water-surface profiles of much larger discharges. The water-surface profile for discharges at and above $124 \mathrm{ft}^{3} / \mathrm{s}$ were appropriate and did not cross. To correct for this, an alternate post-dam-removal model was generated that did not include the diversion channel. The water-surface profile for discharges below $124 \mathrm{ft}^{3} / \mathrm{s}$ was generated from this alternate post-dam-removal model.

The Bradford Dam, Hyde Pond Dam, and Hughesville Dam one-dimensional models had downstream boundary normal-depth slopes of $0.00018,0.0050$, and 0.00561 , respectively. These slopes were computed by using the lidar elevations representing the water surface of the channel reach immediately downstream from the downstream boundary without bathymetry merged into the lidar. Lidar-derived water surface closely represents the hydraulic grade of the channel at the time of the lidar flights.

The normal-depth slope for the White Rock Dam model of 0.00124 was determined by using the channel-bed slope of the downstream 410 feet of the model. The normal-depth slope for the Pond Lily Dam model of 0.0174 was determined from the water-surface profile of the effective flood insurance study for the location of the downstream cross section.

For the Wreck Pond Brook Outfall model, the watersurface elevation at the downstream boundary was the coastal mean higher high water for flood discharge and was mean sea-level for the mean monthly April discharge. These mean elevations are from the National Oceanic and Atmospheric Administration's Long Branch Fishing Pier, N.J. (station identifier: 8531991), tidal station. Although this tidal station is 11 miles north of Wreck Pond Brook, it is the closest tidal station in open coastal waters. The mean higher high water elevation is 2.25 feet, relative to the North American Vertical Datum 1988 (NAVD 88). The mean sea level elevation is -0.24 feet, NAVD 88 . The gates at the upstream end of the outfall were assumed to be fully open for all discharges in both the pre- and post-culvert-retrofit models.

\section{Two-Dimensional Hydraulic Models}

The downstream boundary conditions for all twodimensional models were the same as the one-dimensional models except for four cases. The downstream water surface for the Whittenton Dam and West Britannia Dam pre- and post-dam-removal models were taken directly from the one-dimensional Mill River model in the form of a rating curve. This was because the one-dimensional model encompassed these models, so it provided known water-surface elevations for the downstream boundary conditions of the two-dimensional models. The third case was the post-damremoval model of West Britannia Dam for the 0.2-percent AEP discharge. This model proved to be unsolvable by HEC-RAS, so known water-surface elevations immediately downstream from the two-dimensional mesh at both the main channel and diversion channel outlets were taken from the one-dimensional model in the form of rating curves.

The fourth case where the downstream boundary condition varied from the one-dimensional model was the postculvert-retrofit model of Wreck Pond Brook Outfall for the 0.2-percent AEP discharge. The model proved to be unstable at this large discharge, so known water-surface elevations immediately upstream from the outfall structure from the post-culvert-retrofit one-dimensional model were used as a rating curve at the downstream side of the two-dimensional mesh in the post-culvert-retrofit model for the 0.2-percent AEP discharge. 
Meshes used in the two-dimensional models varied in area. The lengths of the two-dimensional meshes are discussed in "Development of Hydraulic Models" section. The widths covered the entire floodplain in each model. The mesh cell size was chosen so that at least three cells traversed the channel beds for fish passage evaluations. The two-dimensional meshes for the models consisted of 10-foot cells enforced to breaklines at selected locations. The exception was the mesh for the Wreck Pond Brook Outfall model, which used 30-foot cells. Breaklines were set in all models to force the HEC-RAS mesh generator to create finer and more detailed cells that were aligned with structures and changes in topography such as the tops and bottoms of channel banks.

Since two-dimensional model simulations are intended for unsteady flow modeling, the input discharge of interest for all two-dimensional models was held constant and the model iterated until it reached equilibrium. This equilibrium was evaluated in terms of inflow and outflow of the two-dimensional mesh and at cross sections upstream and downstream from the mesh. The equilibrium was also evaluated in terms of steady water-surface elevations in the cells of the two-dimensional mesh and in cross sections upstream or downstream from the mesh. Holding the inflow discharge constant was done through the warmup periods of the twodimensional models and into the modeling period until the model reached equilibrium.

The time step of the iterations in the models varied on the basis of the model, mesh cell size, and the discharge being evaluated. The time steps varied from 1 to 60 seconds, and a few model scenarios were set to have the time step controlled by the Courant condition (Brunner, 2016).

\section{Model Results}

Selected results from the HEC-RAS models are provided in tables 4 through 12 . Water-surface elevations at locations upstream from the dams are shown from both pre- and postdam-removal models as computed by both the one- and twodimensional models for all discharges modeled. The locations upstream from the dam correspond to where the approach cross sections are in the one-dimensional models. For the

Table 4. Water-surface elevations at the dam approach cross section at the Whittenton Dam study site in Taunton, Massachusetts.

[NAVD 88, North American Vertical Datum of 1988; AEP, annual exceedance probability; --, not determined]

\begin{tabular}{lcccc}
\hline & $\begin{array}{c}\text { Water-surface elevation at approach location } \\
\text { with dam, in feet NAVD 88 }\end{array}$ & $\begin{array}{c}\text { Water-surface elevation at approach location } \\
\text { without dam, in feet NAVD 88 }\end{array}$ \\
\cline { 2 - 5 } & $\begin{array}{c}\text { One-dimensional } \\
\text { model }\end{array}$ & $\begin{array}{c}\text { Two-dimensional } \\
\text { model }\end{array}$ & $\begin{array}{c}\text { One-dimensional } \\
\text { model }\end{array}$ & $\begin{array}{c}\text { Two-dimensional } \\
\text { model }\end{array}$ \\
\hline 0.2-percent AEP flood & 59.90 & 60.12 & 54.03 & 53.81 \\
0.5-percent AEP flood & 59.54 & -- & 53.33 & -- \\
1-percent AEP flood & 59.27 & 59.45 & 52.82 & 52.84 \\
2-percent AEP flood & 59.01 & 59.17 & 52.38 & 52.44 \\
4-percent AEP flood & 58.75 & -- & 51.95 & -- \\
10-percent AEP flood & 58.41 & 58.54 & 51.45 & 51.56 \\
20-percent AEP flood & 58.16 & -- & 51.11 & -- \\
50-percent AEP flood & 57.78 & 57.87 & 50.70 & -- \\
January mean monthly & 56.34 & -- & 49.10 & -- \\
February mean monthly & 56.37 & -- & 49.14 & 49.40 \\
March mean monthly & 56.68 & 56.80 & 49.47 & 49.30 \\
April mean monthly & 56.56 & 56.70 & 49.34 & -- \\
May mean monthly & 56.13 & -- & 48.91 & -- \\
June mean monthly & 56.07 & -- & 48.87 & -- \\
July mean monthly & 55.66 & -- & 48.50 & 48.37 \\
August mean monthly & 55.46 & 55.60 & 48.32 & - \\
September mean monthly & 55.56 & -- & 48.42 & - \\
October mean monthly & 55.80 & -- & 48.60 & -- \\
November mean monthly & 56.16 & -- & 48.94 & -- \\
December mean monthly & 56.26 & -- & 49.03 & 48.95 \\
Median mean monthly & 56.15 & 56.28 & 48.93 & \\
\hline
\end{tabular}




\section{Hydraulic Modeling at Selected Dam-Removal and Culvert-Retrofit Sites in the Northeastern United States}

Table 5. Water-surface elevations at the approach to the dam and canal at the West Britannia Dam study site in Taunton, Massachusetts.

[NAVD 88, North American Vertical Datum of 1988; AEP, annual exceedance probability; --, not determined]

\begin{tabular}{lcccc}
\hline \multirow{2}{*}{\multicolumn{1}{c}{ Discharge statistic }} & $\begin{array}{c}\text { Water-surface elevation at approach location } \\
\text { with dam, in feet NAVD 88 }\end{array}$ & $\begin{array}{c}\text { Water-surface elevation at approach location } \\
\text { without dam, in feet NAVD 88 }\end{array}$ \\
\cline { 2 - 5 } & $\begin{array}{c}\text { One-dimensional } \\
\text { model }\end{array}$ & $\begin{array}{c}\text { Two-dimensional } \\
\text { model }\end{array}$ & $\begin{array}{c}\text { One-dimensional } \\
\text { model }\end{array}$ & $\begin{array}{c}\text { Two-dimensional } \\
\text { model }\end{array}$ \\
\hline 0.2-percent AEP flood & 48.91 & 48.69 & 45.58 & 45.99 \\
0.5-percent AEP flood & 48.45 & -- & 44.95 & -- \\
1-percent AEP flood & 48.10 & 48.02 & 44.60 & 45.27 \\
2-percent AEP flood & 47.77 & 47.70 & 44.30 & 44.91 \\
4-percent AEP flood & 47.46 & -- & -- \\
10-percent AEP flood & 47.03 & 46.97 & 44.01 & 44.02 \\
20-percent AEP flood & 46.68 & -- & -- \\
50-percent AEP flood & 46.17 & 46.19 & 43.61 & 42.85 \\
January mean monthly & 44.53 & -- & 42.70 & - \\
February mean monthly & 44.58 & -- & 42.78 & -- \\
March mean monthly & 44.84 & 44.88 & 40.79 & 41.27 \\
April mean monthly & 44.74 & 44.77 & 41.12 & 41.14 \\
May mean monthly & 44.34 & -- & 41.00 & -- \\
June mean monthly & 44.28 & -- & 40.53 & - \\
July mean monthly & 43.84 & -- & 40.48 & - \\
August mean monthly & 43.57 & 43.38 & 39.98 & 39.79 \\
September mean monthly & 43.70 & -- & 39.72 & -- \\
October mean monthly & 44.02 & -- & 39.85 & -- \\
November mean monthly & 44.37 & -- & 40.16 & -- \\
December mean monthly & 44.46 & -- & 40.58 & -- \\
Median mean monthly & 44.35 & 44.33 & 40.69 & 40.65 \\
\hline
\end{tabular}


Table 6. Water-surface elevations at the dam approach cross section at the Hopewell Dam study site in Taunton, Massachusetts.

[NAVD 88, North American Vertical Datum of 1988; AEP, annual exceedance probability; --, not determined]

\begin{tabular}{|c|c|c|c|c|}
\hline \multirow{2}{*}{ Discharge statistic } & \multicolumn{2}{|c|}{$\begin{array}{l}\text { Water-surface elevation at approach location } \\
\text { with dam, in feet NAVD } 88\end{array}$} & \multicolumn{2}{|c|}{$\begin{array}{c}\text { Water-surface elevation at approach location } \\
\text { without dam, in feet NAVD } 88\end{array}$} \\
\hline & $\begin{array}{l}\text { One-dimensional } \\
\text { model }\end{array}$ & $\begin{array}{l}\text { Two-dimensional } \\
\text { model }\end{array}$ & $\begin{array}{l}\text { One-dimensional } \\
\text { model }\end{array}$ & $\begin{array}{l}\text { Two-dimensional } \\
\text { model }\end{array}$ \\
\hline 0.2-percent AEP flood & 42.86 & 42.95 & 32.50 & 31.96 \\
\hline 0.5-percent AEP flood & 42.48 & -- & 32.08 & -- \\
\hline 1-percent AEP flood & 42.13 & 42.32 & 31.76 & 31.31 \\
\hline 4-percent AEP flood & 40.97 & -- & 31.09 & -- \\
\hline 10-percent AEP flood & 40.20 & 40.65 & 30.64 & 30.36 \\
\hline 20-percent AEP flood & 39.62 & -- & 30.28 & -- \\
\hline 50-percent AEP flood & 38.79 & 39.26 & 29.76 & 29.57 \\
\hline April mean monthly & 36.74 & 37.12 & 28.25 & 28.14 \\
\hline May mean monthly & 36.26 & -- & 27.79 & -- \\
\hline June mean monthly & 36.20 & -- & 27.74 & -- \\
\hline July mean monthly & 35.78 & -- & 27.83 & -- \\
\hline August mean monthly & 35.59 & 35.79 & 27.31 & 27.12 \\
\hline September mean monthly & 35.68 & -- & 27.11 & -- \\
\hline October mean monthly & 35.92 & -- & 27.21 & -- \\
\hline November mean monthly & 36.30 & -- & 27.46 & -- \\
\hline December mean monthly & 36.40 & -- & 27.83 & -- \\
\hline
\end{tabular}


$24 \quad$ Hydraulic Modeling at Selected Dam-Removal and Culvert-Retrofit Sites in the Northeastern United States

Table 7. Water-surface elevations at the dam approach cross section at the Bradford Dam study site in Westerly, Rhode Island.

[NAVD 88, North American Vertical Datum of 1988; AEP, annual exceedance probability; --, not determined]

\begin{tabular}{|c|c|c|c|c|}
\hline \multirow{2}{*}{ Discharge statistic } & \multicolumn{2}{|c|}{$\begin{array}{l}\text { Water-surface elevation at approach location } 1 \\
\text { with dam, in feet NAVD } 88\end{array}$} & \multicolumn{2}{|c|}{$\begin{array}{c}\text { Water-surface elevation at approach location' } \\
\text { without dam, in feet NAVD } 88\end{array}$} \\
\hline & $\begin{array}{c}\text { One-dimensional } \\
\text { model }\end{array}$ & $\begin{array}{l}\text { Two-dimensional } \\
\text { model }\end{array}$ & $\begin{array}{c}\text { One-dimensional } \\
\text { model }\end{array}$ & $\begin{array}{l}\text { Two-dimensional } \\
\text { model }\end{array}$ \\
\hline 0.2-percent AEP flood & 39.32 & 39.36 & 39.09 & 39.13 \\
\hline 0.5-percent AEP flood & 38.37 & -- & 38.23 & -- \\
\hline 1-percent AEP flood & 37.72 & 37.96 & 37.53 & 37.54 \\
\hline 2-percent AEP flood & 36.84 & 37.32 & 36.67 & 36.75 \\
\hline 4-percent AEP flood & 36.07 & -- & 35.98 & -- \\
\hline 10-percent AEP flood & 35.09 & 36.27 & 35.15 & 35.07 \\
\hline 20-percent AEP flood & 34.64 & -- & 34.91 & -- \\
\hline 50-percent AEP flood & 34.33 & 35.47 & 34.61 & 33.54 \\
\hline January mean monthly & 34.14 & -- & 33.32 & -- \\
\hline February mean monthly & 34.14 & -- & 33.37 & -- \\
\hline March mean monthly & 34.15 & 34.70 & 33.60 & 33.68 \\
\hline April mean monthly & 34.15 & 34.67 & 33.58 & 33.66 \\
\hline May mean monthly & 34.14 & -- & 33.29 & -- \\
\hline June mean monthly & 34.06 & -- & 33.06 & -- \\
\hline July mean monthly & 33.59 & -- & 32.73 & -- \\
\hline August mean monthly & 33.45 & -- & 32.63 & -- \\
\hline September mean monthly & 33.43 & 33.43 & 32.62 & 32.59 \\
\hline October mean monthly & 33.56 & -- & 32.71 & -- \\
\hline November mean monthly & 33.94 & -- & 32.98 & -- \\
\hline December mean monthly & 34.14 & -- & 33.22 & -- \\
\hline Median mean monthly & 34.15 & 34.19 & 33.15 & 33.19 \\
\hline
\end{tabular}


Table 8. Water-surface elevations at the approach to the dam and canal at the White Rock Dam study site in Westerly, Rhode Island.

[NAVD 88, North American Vertical Datum of 1988; AEP, annual exceedance probability; --, not determined]

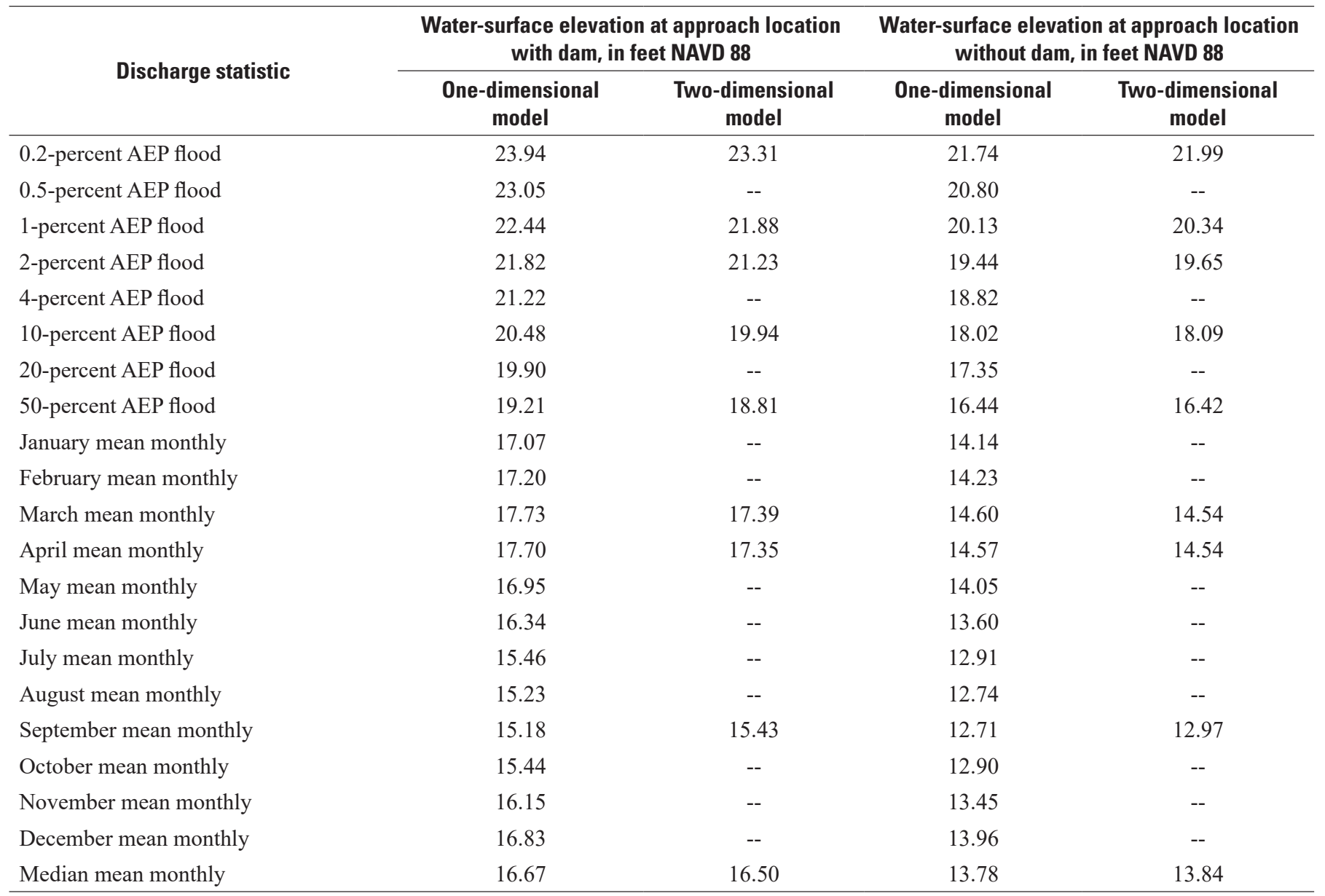




\section{Hydraulic Modeling at Selected Dam-Removal and Culvert-Retrofit Sites in the Northeastern United States}

Table 9. Water-surface elevations at the dam approach cross section at the Hyde Pond Dam study site in Mystic, Connecticut.

[NAVD 88, North American Vertical Datum of 1988; AEP, annual exceedance probability; --, not determined]

\begin{tabular}{|c|c|c|c|c|}
\hline \multirow{2}{*}{ Discharge statistic } & \multicolumn{2}{|c|}{$\begin{array}{l}\text { Water-surface elevation at approach location } \\
\text { with dam, in feet NAVD } 88\end{array}$} & \multicolumn{2}{|c|}{$\begin{array}{c}\text { Water-surface elevation at approach location } \\
\text { without dam, in feet NAVD } 88\end{array}$} \\
\hline & $\begin{array}{l}\text { One-dimensional } \\
\text { model }\end{array}$ & $\begin{array}{l}\text { Two-dimensional } \\
\text { model }\end{array}$ & $\begin{array}{l}\text { One-dimensional } \\
\text { model }\end{array}$ & $\begin{array}{l}\text { Two-dimensional } \\
\text { model }\end{array}$ \\
\hline 0.2-percent AEP flood & 22.76 & 23.09 & 20.40 & 19.92 \\
\hline 0.5-percent AEP flood & 22.52 & -- & 19.83 & -- \\
\hline 1-percent AEP flood & 22.31 & 22.62 & 19.27 & 19.22 \\
\hline 4-percent AEP flood & 21.81 & -- & 18.14 & -- \\
\hline 10-percent AEP flood & 21.46 & 21.71 & 17.43 & 17.58 \\
\hline 20-percent AEP flood & 21.17 & -- & 16.89 & -- \\
\hline 50-percent AEP flood & 20.75 & 20.87 & 16.10 & 16.06 \\
\hline April mean monthly & 19.12 & 19.13 & 14.05 & 14.13 \\
\hline May mean monthly & 19.05 & -- & 13.94 & -- \\
\hline June mean monthly & 18.98 & -- & 13.84 & -- \\
\hline July mean monthly & 18.86 & -- & 13.67 & -- \\
\hline August mean monthly & 18.85 & 18.84 & 13.64 & 13.71 \\
\hline September mean monthly & 18.85 & -- & 13.65 & -- \\
\hline October mean monthly & 18.90 & -- & 13.74 & -- \\
\hline November mean monthly & 19.00 & -- & 13.87 & -- \\
\hline December mean monthly & 19.08 & -- & 13.98 & -- \\
\hline
\end{tabular}

Table 10. Water-surface elevations at the dam approach cross section at the Pond Lily Dam study site in New Haven, Connecticut.

[NAVD 88; North American Vertical Datum of 1988; AEP, annual exceedance probability; --, not determined]

\begin{tabular}{|c|c|c|c|c|}
\hline \multirow{2}{*}{ Discharge statistic } & \multicolumn{2}{|c|}{$\begin{array}{c}\text { Water-surface elevation at approach location } \\
\text { with dam, in feet NAVD } 88\end{array}$} & \multicolumn{2}{|c|}{$\begin{array}{c}\text { Water-surface elevation at approach location } \\
\text { without dam, in feet NAVD } 88\end{array}$} \\
\hline & $\begin{array}{l}\text { One-dimensional } \\
\text { model }\end{array}$ & $\begin{array}{l}\text { Two-dimensional } \\
\text { model }\end{array}$ & $\begin{array}{l}\text { One-dimensional } \\
\text { model }\end{array}$ & $\begin{array}{l}\text { Two-dimensional } \\
\text { model }\end{array}$ \\
\hline 0.2-percent AEP flood & 78.79 & 78.98 & 77.88 & 76.62 \\
\hline 0.5 -percent AEP flood & 78.59 & -- & 77.45 & -- \\
\hline 1-percent AEP flood & 78.40 & 78.72 & 77.09 & 75.84 \\
\hline 4-percent AEP flood & 77.94 & -- & 76.46 & -- \\
\hline 10-percent AEP flood & 77.62 & 78.03 & 75.71 & 74.58 \\
\hline 20-percent AEP flood & 77.35 & -- & 75.04 & -- \\
\hline 50-percent AEP flood & 76.94 & 77.30 & 73.98 & 73.42 \\
\hline June median monthly & 75.90 & -- & 70.69 & -- \\
\hline July-October median monthly & 75.87 & 76.14 & 70.46 & 70.67 \\
\hline November median monthly & 75.94 & -- & 70.84 & -- \\
\hline Median of median monthlies & 75.95 & 76.23 & 70.91 & 70.99 \\
\hline
\end{tabular}


Table 11. Water-surface elevations at the dam approach cross section at the Hughesville Dam study site in Warren Glen, New Jersey.

[NAVD 88, North American Vertical Datum of 1988; AEP, annual exceedance probability; --, not determined]

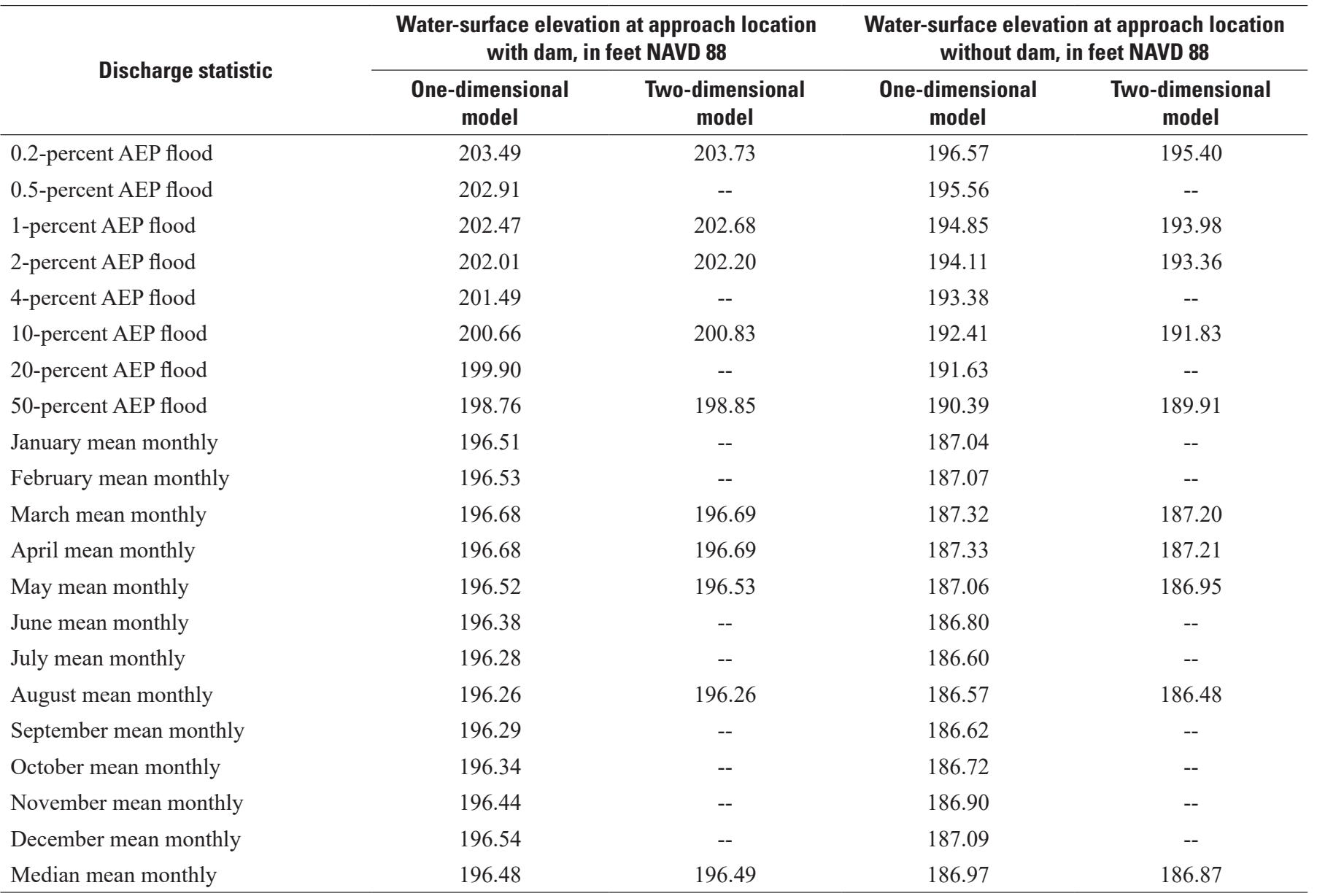

Table 12. Water-surface elevations at the approach cross section to the outfall at the Wreck Pond Brook Outfall study site in Spring Lake, New Jersey.

[NAVD 88, North American Vertical Datum of 1988; AEP, annual exceedance probability; --, not determined]

\begin{tabular}{|c|c|c|c|c|}
\hline \multirow{2}{*}{ Discharge statistic } & \multicolumn{2}{|c|}{$\begin{array}{l}\text { Water-surface elevation at approach location } \\
\text { without culvert retrofit, in feet NAVD } 88\end{array}$} & \multicolumn{2}{|c|}{$\begin{array}{c}\text { Water-surface elevation at approach location } \\
\text { with culvert retrofit, in feet NAVD } 88\end{array}$} \\
\hline & $\begin{array}{l}\text { One-dimensional } \\
\text { model }\end{array}$ & $\begin{array}{l}\text { Two-dimensional } \\
\text { model }\end{array}$ & $\begin{array}{l}\text { One-dimensional } \\
\text { model }\end{array}$ & $\begin{array}{l}\text { Two-dimensional } \\
\text { model }\end{array}$ \\
\hline 0.2-percent AEP flood & 13.10 & 13.30 & 9.95 & 9.95 \\
\hline 0.5 -percent AEP flood & 12.83 & -- & 9.95 & -- \\
\hline 1-percent AEP flood & 12.61 & 12.73 & 8.92 & 9.00 \\
\hline 4-percent AEP flood & 12.04 & -- & 5.88 & -- \\
\hline 10-percent AEP flood & 11.29 & 11.16 & 4.40 & 4.43 \\
\hline 20-percent AEP flood & 8.87 & -- & 3.58 & -- \\
\hline 50-percent AEP flood & 4.94 & 5.12 & 2.82 & 2.83 \\
\hline
\end{tabular}


Wreck Pond Brook Outfall study site, water-surface elevations at the approach to the outfall structure are provided. The approach cross sections are identified on the inundation maps in figures 2 through 10 and are within 50 to 285 feet upstream from the structure, depending on site configuration. At all sites, except the Bradford Dam study site, the water-surface elevations for all discharges decreased with the dam removal or culvert retrofit.

To further demonstrate the changes in elevation due to the removal of a dam, water-surface profile plots of the Hyde Pond Dam study site for the 1-percent AEP discharge and the mean monthly April discharge are provided in figure 11. The profile plots show the decrease in water surface elevation upstream from the dam location following dam removal.

The effect of the decrease in water surface following the dam removal is shown in inundation maps. Inundation maps were generated for the 1-percent AEP discharge before and after the dam removal or culvert retrofit for all the study sites (figs. 2-10). The inundation maps were developed from the results of the one-dimensional models. Some maps show a substantial change in the inundated area when the dam is removed - some do not. For example, figure 2 shows that
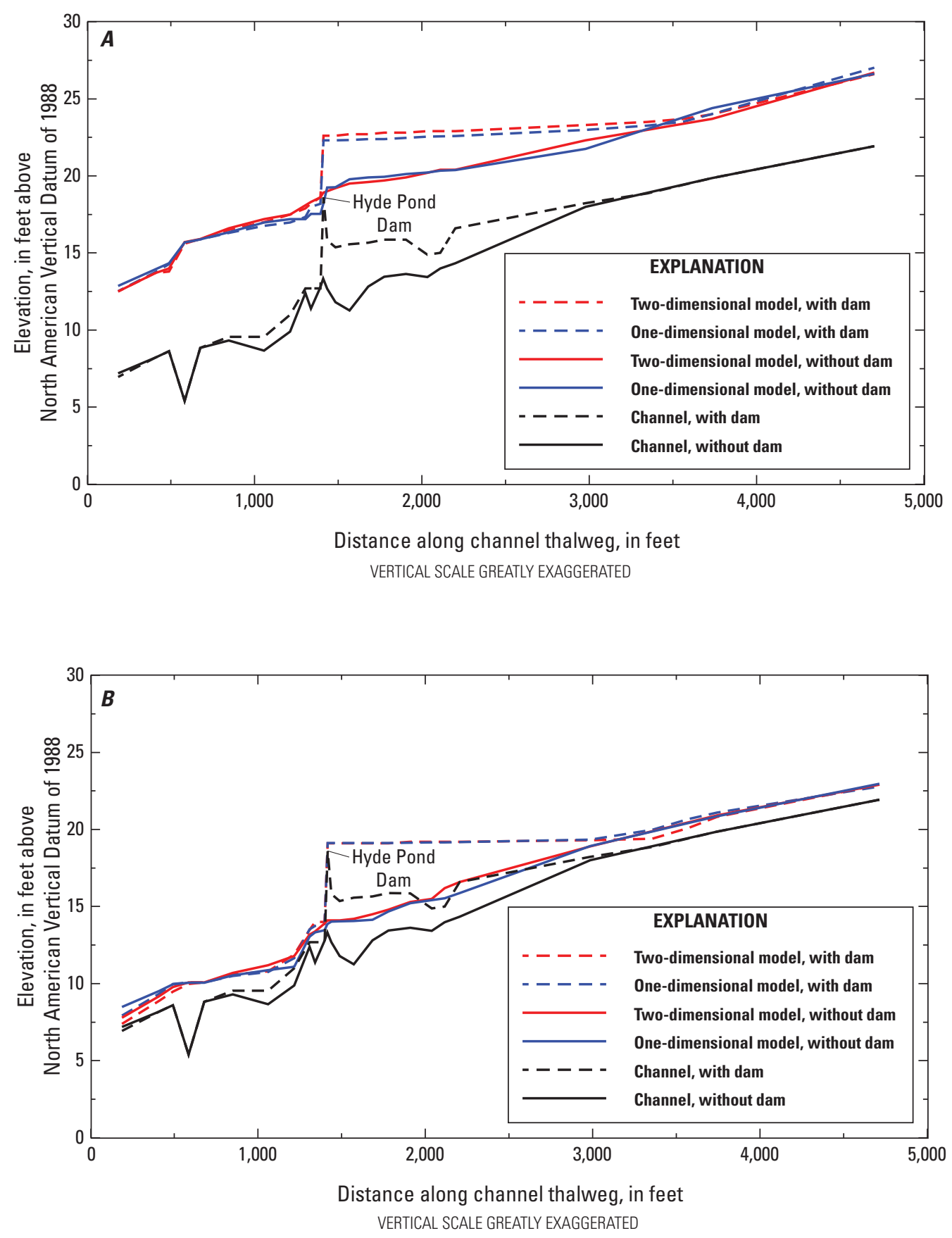

Figure 11. Profile plots of the A, 1-percent annual exceedance probability discharge and $B$, April mean monthly discharge water-surface elevation at the Hyde Pond study reach in Mystic, Connecticut. 
removing the Whittenton Dam results in substantially less area inundated by the 1-percent AEP flood discharge. But at the White Rock Dam study site shown in figure 6, the inundated area does not change substantially. This is because of the topography of the floodplain upstream from the dam location.

On all the inundation maps, water is shown on bridge decks. This is because the DEMs do not include the elevations of the deck. The 1-percent AEP water surface does not overtop the bridge decks at any of the sites. In addition, there are two inundation figures that have some unusual features that warrant discussion. The first is figure 2, the map of Whittenton Dam. At the very downstream end of the study reach is area shown as inundated by the pre-dam-removal model that is not inundated by the post-dam-removal model. The difference here is partially due to some elevation detail on the post-dam-removal DEM that is not present on the pre-damremoval DEM and partially due to the pre-dam-removal model having a water-surface elevation 0.2 foot higher than the post-dam-removal model. The higher water-surface elevation is due to the West Britannia Dam downstream. The second inundation figure with an unusual feature is figure 4, the map of the Hopewell Mills Dam inundation area. Immediately downstream from the dam location, the inundated area of the post-dam-removal model is greater than that of the pre-damremoval model. This is due to the size of the earthen dam that was removed and the shape of its spillway.

Velocity data results from the two-dimensional models are provided for the study sites in tables 13 through 21 . The velocity data are for locations corresponding to the approach cross section in the one-dimensional models and at the dam sites (figs. 2-10). Velocities for the pre- and post-dam-removal scenarios at the discharges modeled are provided near the thalweg of the channel and at locations towards the left and right sides of the channel. The left and right locations were chosen subjectively, but they typically represented velocity close to the channel bank. At the Wreck Pond Brook Outfall site, velocities are shown for the approach to the outfall and within the culverts of the outfall structure.

Fish passage criteria for all the sites were analyzed. Fish passage analysis was based upon criteria of minimum water depth and velocity for selected species during the species' peak migration month, as provided by FWS (Jessica Pica, U.S. Fish and Wildlife Service, written commun., 2020). The FWS also selected the target species for each study site. Table 22 shows the criteria used for each of the study reaches and if the criteria were met on the basis of model results for the given discharge applicable to the peak migration month. Prolonged swim velocity in table 22 is the velocity that the selected fish can swim for 5 to 8 minutes. Burst swim velocity is the velocity that the selected fish can swim for up to 10 seconds (U.S. Fish and Wildlife Service, 2019b). Target species included river herring (alewife [Alosa pseudoherengus] and blueback herring [Alosa aestivalis]) and American shad (Alosa sapidissima).

Water depths were taken directly from RAS Mapper in HEC-RAS, and at all sites the depth criteria were met. In several instances, the water velocities exceeded the prolonged swim velocities of selected species. Table 22 indicates the velocity and length of the stream by which the prolonged swim velocity was exceeded. The lengths were visualized and measured by using the RAS Mapper tools in HEC-RAS and are approximate. If the prolonged swim velocity was exceeded, the difference between the maximum burst swim velocity and the minimum velocity in the reach where prolonged swim velocity was exceeded was found and multiplied by 10 seconds to find the distance the selected fish could travel. If the computed distance was less than the maximum distance the prolonged swim velocity was exceeded, the table indicates that there is an obstacle to fish passage. However, analysis of fish passage success is more complicated than

Table 13. Water velocities from the two-dimensional models at the dam approach and where the dam was once located at the Whittenton Dam study site in Taunton, Massachusetts.

[AEP, annual exceedance probability]

\begin{tabular}{|c|c|c|c|c|c|c|c|c|c|}
\hline \multirow{2}{*}{ Discharge statistic } & \multicolumn{3}{|c|}{$\begin{array}{l}\text { Velocity at approach location with } \\
\text { dam, in feet per second }\end{array}$} & \multicolumn{3}{|c|}{$\begin{array}{l}\text { Velocity at approach location with- } \\
\text { out dam, in feet per second }\end{array}$} & \multicolumn{3}{|c|}{$\begin{array}{l}\text { Velocity at dam location without } \\
\text { dam, in feet per second }\end{array}$} \\
\hline & Left & $\begin{array}{l}\text { Thalweg or } \\
\text { maximum }\end{array}$ & Right & Left & $\begin{array}{l}\text { Thalweg or } \\
\text { maximum }\end{array}$ & Right & Left & $\begin{array}{c}\text { Thalweg or } \\
\text { maximum }\end{array}$ & Right \\
\hline 0.2-percent AEP flood & 3.0 & 3.9 & 3.7 & 6.6 & 8.7 & 3.8 & 4.9 & 8.5 & 4.0 \\
\hline 1-percent AEP flood & 2.5 & 3.4 & 3.2 & 6.0 & 8.2 & 3.7 & 4.2 & 8.0 & 3.5 \\
\hline 2-percent AEP flood & 2.3 & 3.2 & 3.0 & 5.8 & 8.0 & 3.5 & 4.0 & 7.8 & 3.4 \\
\hline 50-percent AEP flood & 1.2 & 2.2 & 2.0 & 4.6 & 6.8 & 2.3 & 5.6 & 6.6 & 3.7 \\
\hline March mean monthly & 0.5 & 1.4 & 1.2 & 3.2 & 5.3 & 2.1 & 4.0 & 4.7 & 1.7 \\
\hline April mean monthly & 0.4 & 1.3 & 1.1 & 3.0 & 5.1 & 1.8 & 3.8 & 4.5 & 2.0 \\
\hline August mean monthly & 0.3 & 1.0 & 0.7 & 1.4 & 3.0 & 2.7 & 1.3 & 1.6 & 1.4 \\
\hline Median mean monthly & 0.1 & 0.3 & 0.1 & 2.2 & 4.5 & 3.2 & 2.9 & 3.5 & 3.2 \\
\hline
\end{tabular}


Table 14. Water velocities from the two-dimensional models at the approach to the dam and canal and where the dam was once located at the West Britannia Dam study site in Taunton, Massachusetts.

[AEP, annual exceedance probability]

\begin{tabular}{|c|c|c|c|c|c|c|c|c|c|}
\hline \multirow{2}{*}{ Discharge statistic } & \multicolumn{3}{|c|}{$\begin{array}{l}\text { Velocity at approach location with } \\
\text { dam, in feet per second }\end{array}$} & \multicolumn{3}{|c|}{$\begin{array}{l}\text { Velocity at approach location with- } \\
\text { out dam, in feet per second }\end{array}$} & \multicolumn{3}{|c|}{$\begin{array}{l}\text { Velocity at dam location without } \\
\text { dam, in feet per second }\end{array}$} \\
\hline & Left & $\begin{array}{l}\text { Thalweg or } \\
\text { maximum }\end{array}$ & Right & Left & $\begin{array}{l}\text { Thalweg or } \\
\text { maximum }\end{array}$ & Right & Left & $\begin{array}{l}\text { Thalweg or } \\
\text { maximum }\end{array}$ & Right \\
\hline 0.2-percent AEP flood & 1.3 & 4.6 & 1.2 & 5.4 & 9.1 & 5.3 & 8.1 & 8.3 & 5.3 \\
\hline 1-percent AEP flood & 1.0 & 4.0 & 0.9 & 6.2 & 8.5 & 4.6 & 7.1 & 7.4 & 4.7 \\
\hline 2-percent AEP flood & 0.9 & 3.7 & 0.8 & 5.9 & 8.2 & 6.4 & 6.9 & 7.3 & 4.5 \\
\hline 50-percent AEP flood & 0.5 & 2.4 & 0.4 & 4.0 & 6.0 & 4.3 & 5.5 & 6.4 & 5.3 \\
\hline March mean monthly & 0.5 & 1.2 & 0.8 & 3.4 & 3.7 & 2.2 & 3.4 & 4.2 & 3.3 \\
\hline April mean monthly & 0.4 & 1.0 & 0.7 & 2.0 & 3.5 & 2.0 & 3.2 & 4.0 & 3.0 \\
\hline August mean monthly & 0.1 & 0.2 & 0.1 & 1.1 & 1.3 & 1.3 & 1.3 & 1.6 & 0.7 \\
\hline Median mean monthly & 0.3 & 0.7 & 0.3 & 2.4 & 2.7 & 1.5 & 2.7 & 3.3 & 2.3 \\
\hline
\end{tabular}

Table 15. Water velocities from the two-dimensional models at the dam approach and where the dam was once located at the Hopewell Dam study site in Taunton, Massachusetts.

[AEP, annual exceedance probability; <, less than]

\begin{tabular}{|c|c|c|c|c|c|c|c|c|c|}
\hline \multirow{2}{*}{ Discharge statistic } & \multicolumn{3}{|c|}{$\begin{array}{l}\text { Velocity at approach location with } \\
\text { dam, in feet per second }\end{array}$} & \multicolumn{3}{|c|}{$\begin{array}{l}\text { Velocity at approach location without } \\
\text { dam, in feet per second }\end{array}$} & \multicolumn{3}{|c|}{$\begin{array}{l}\text { Velocity at dam location without } \\
\text { dam, in feet per second }\end{array}$} \\
\hline & Left & $\begin{array}{l}\text { Thalweg or } \\
\text { maximum }\end{array}$ & Right & Left & $\begin{array}{l}\text { Thalweg or } \\
\text { maximum }\end{array}$ & Right & Left & $\begin{array}{l}\text { Thalweg or } \\
\text { maximum }\end{array}$ & Right \\
\hline 0.2-percent AEP flood & 1.4 & 3.2 & 1.6 & 5.1 & 6.6 & 6 & 4.9 & 7.5 & 6.3 \\
\hline 1-percent AEP flood & 1.2 & 2.8 & 1.5 & 4.3 & 5.9 & 5.1 & 4.0 & 6.5 & 5.4 \\
\hline 2-percent AEP flood & 1.1 & 2.7 & 1.4 & 4.0 & 5.6 & 4.8 & 3.7 & 6.1 & 5.0 \\
\hline 50-percent AEP flood & 0.6 & 1.8 & 0.8 & 2.3 & 3.8 & 2.9 & 2.0 & 4.1 & 2.8 \\
\hline March mean monthly & 0.4 & 0.9 & 0.3 & 1.7 & 2.2 & 1.7 & 1.8 & 2.2 & 1.1 \\
\hline April mean monthly & 0.3 & 0.8 & 0.3 & 1.6 & 2.1 & 1.6 & 1.7 & 2.1 & 1.0 \\
\hline August mean monthly & $<0.1$ & $<0.1$ & $<0.1$ & 0.5 & 0.6 & 0.3 & 0.4 & 0.5 & 0.3 \\
\hline Median mean monthly & 0.2 & 0.7 & 0.2 & 1.5 & 1.6 & 1.1 & 1.3 & 1.5 & 0.6 \\
\hline
\end{tabular}

Table 16. Water velocities from the two-dimensional models at the dam approach and where the dam was once located at the Bradford Dam study site in Westerly, Rhode Island.

[AEP, annual exceedance probability]

\begin{tabular}{|c|c|c|c|c|c|c|c|c|c|}
\hline \multirow{2}{*}{ Discharge statistic } & \multicolumn{3}{|c|}{$\begin{array}{l}\text { Velocity at approach location }{ }^{1} \\
\text { with dam, in feet per second }\end{array}$} & \multicolumn{3}{|c|}{$\begin{array}{l}\text { Velocity at approach location }{ }^{1} \\
\text { without dam, in feet per second }\end{array}$} & \multicolumn{3}{|c|}{$\begin{array}{l}\text { Velocity at dam location without } \\
\text { dam, in feet per second }\end{array}$} \\
\hline & Left & $\begin{array}{l}\text { Thalweg or } \\
\text { maximum }\end{array}$ & Right & Left & $\begin{array}{l}\text { Thalweg or } \\
\text { maximum }\end{array}$ & Right & Left & $\begin{array}{l}\text { Thalweg or } \\
\text { maximum }\end{array}$ & Right \\
\hline 0.2-percent AEP flood & 2.1 & 3.9 & 2.8 & 2.7 & 4.5 & 3.4 & 3.5 & 3.5 & 3.0 \\
\hline 1-percent AEP flood & 1.9 & 3.8 & 2.7 & 2.7 & 4.8 & 3.2 & 3.1 & 3.3 & 2.0 \\
\hline 2-percent AEP flood & 1.7 & 3.6 & 2.5 & 2.4 & 4.9 & 3.1 & 3.0 & 3.2 & 1.8 \\
\hline 50-percent AEP flood & 1.2 & 1.9 & 1.9 & 1.3 & 4.5 & 2.9 & 2.5 & 2.6 & 1.7 \\
\hline March mean monthly & 0.7 & 1.1 & 0.4 & 0.8 & 2.2 & 1.3 & 2.4 & 2.5 & 2.0 \\
\hline April mean monthly & 0.7 & 1.1 & 0.4 & 0.8 & 2.1 & 1.3 & 2.4 & 2.5 & 2.1 \\
\hline September mean monthly & 0.2 & 0.3 & 0.2 & 0.5 & 0.6 & 0.3 & 0.3 & 1.4 & 0.2 \\
\hline Median mean monthly & 0.4 & 0.8 & 0.4 & 0.6 & 1.3 & 0.8 & 1.2 & 2.1 & 1.3 \\
\hline
\end{tabular}

\footnotetext{
${ }^{1}$ Approach location without dam is approximately 80 feet farther upstream due to weirs upstream from dam location.
} 
Table 17. Water velocities from the two-dimensional models at the approach to the dam and canal and where the dam was once located at the White Rock Dam study site in Westerly, Rhode Island.

[AEP, annual exceedance probability]

\begin{tabular}{|c|c|c|c|c|c|c|c|c|c|}
\hline \multirow{2}{*}{ Discharge statistic } & \multicolumn{3}{|c|}{$\begin{array}{l}\text { Velocity at approach location with } \\
\text { dam, in feet per second }\end{array}$} & \multicolumn{3}{|c|}{$\begin{array}{l}\text { Velocity at approach location } \\
\text { without dam, in feet per second }\end{array}$} & \multicolumn{3}{|c|}{$\begin{array}{l}\text { Velocity at dam location withou } \\
\text { dam, in feet per second }\end{array}$} \\
\hline & Left & $\begin{array}{l}\text { Thalweg or } \\
\text { maximum }\end{array}$ & Right & Left & $\begin{array}{l}\text { Thalweg or } \\
\text { maximum }\end{array}$ & Right & Left & $\begin{array}{l}\text { Thalweg or } \\
\text { maximum }\end{array}$ & Right \\
\hline 0.2-percent AEP flood & 3.9 & 6.4 & 4.0 & 5.1 & 6.8 & 5.0 & 6.8 & 7.2 & 5.1 \\
\hline 1-percent AEP flood & 3.1 & 5.5 & 3.2 & 4.5 & 6.0 & 4.2 & 5.8 & 6.3 & 4.1 \\
\hline 2-percent AEP flood & 2.7 & 5.1 & 2.8 & 3.9 & 5.6 & 4.0 & 5.4 & 5.9 & 4.0 \\
\hline 50-percent AEP flood & 1.0 & 3.3 & 1.3 & 2.0 & 3.0 & 3.0 & 3.5 & 3.9 & 2.2 \\
\hline March mean monthly & 1.1 & 2.0 & 0.6 & 0.9 & 2.5 & 1.0 & 2.1 & 2.4 & 1.8 \\
\hline April mean monthly & 1.1 & 2.0 & 0.6 & 0.9 & 2.5 & 1.0 & 2.1 & 2.4 & 1.8 \\
\hline September mean monthly & 0.4 & 0.7 & 0.1 & 0.4 & 1.0 & 0.8 & 0.6 & 0.7 & 0.5 \\
\hline Median mean monthly & 0.6 & 1.4 & 0.4 & 0.9 & 1.9 & 1.3 & 1.4 & 1.6 & 1.2 \\
\hline
\end{tabular}

Table 18. Water velocities from the two-dimensional models at the dam approach and where the dam was once located at the Hyde Pond Dam study site in Mystic, Connecticut.

[AEP, annual exceedance probability; <, less than]

\begin{tabular}{|c|c|c|c|c|c|c|c|c|c|}
\hline \multirow{2}{*}{ Discharge statistic } & \multicolumn{3}{|c|}{$\begin{array}{l}\text { Velocity at approach location with } \\
\text { dam, in feet per second }\end{array}$} & \multicolumn{3}{|c|}{$\begin{array}{l}\text { Velocity at approach location with- } \\
\text { out dam, in feet per second }\end{array}$} & \multicolumn{3}{|c|}{$\begin{array}{l}\text { Velocity at dam location without } \\
\text { dam, in feet per second }\end{array}$} \\
\hline & Left & $\begin{array}{l}\text { Thalweg or } \\
\text { maximum }\end{array}$ & Right & Left & $\begin{array}{l}\text { Thalweg or } \\
\text { maximum }\end{array}$ & Right & Left & $\begin{array}{l}\text { Thalweg or } \\
\text { maximum }\end{array}$ & Right \\
\hline 0.2-percent AEP flood & 2.1 & 2.2 & 2.1 & 4.1 & 5.3 & 3.9 & 4.7 & 7.5 & 4.7 \\
\hline 1-percent AEP flood & 1.9 & 1.9 & 1.9 & 3.7 & 5.0 & 3.7 & 4.0 & 7.1 & 4.0 \\
\hline 2-percent AEP flood & 1.6 & 1.7 & 1.6 & 3.3 & 4.7 & 3.4 & 3.4 & 7.0 & 3.5 \\
\hline 50-percent AEP flood & 0.7 & 0.8 & 0.6 & 1.9 & 4.1 & 2.8 & 3.0 & 5.2 & 2.9 \\
\hline March mean monthly & 0.1 & 0.1 & $<0.1$ & 0.6 & 0.8 & 0.5 & 1.9 & 2.5 & 1.4 \\
\hline April mean monthly & 0.1 & 0.1 & $<0.1$ & 0.5 & 0.8 & 0.5 & 1.9 & 2.5 & 1.3 \\
\hline August mean monthly & $<0.1$ & $<0.1$ & $<0.1$ & 0.2 & 0.2 & 0.2 & 1.1 & 1.5 & 1.1 \\
\hline Median mean monthly & 0.1 & 0.1 & $<0.1$ & 0.4 & 0.5 & 0.5 & 1.6 & 2.2 & 1.6 \\
\hline
\end{tabular}

Table 19. Water velocities from the two-dimensional models at the dam approach and where the dam was once located at the Pond Lily Dam study site in New Haven, Connecticut.

[AEP, annual exceedance probability; <, less than]

\begin{tabular}{|c|c|c|c|c|c|c|c|c|c|}
\hline \multirow{2}{*}{ Discharge statistic } & \multicolumn{3}{|c|}{$\begin{array}{l}\text { Velocity at approach location with } \\
\text { dam, in feet per second }\end{array}$} & \multicolumn{3}{|c|}{$\begin{array}{l}\text { Velocity at approach location } \\
\text { without dam, in feet per second }\end{array}$} & \multicolumn{3}{|c|}{$\begin{array}{l}\text { Velocity at dam location without } \\
\text { dam, in feet per second }\end{array}$} \\
\hline & Left & $\begin{array}{l}\text { Thalweg or } \\
\text { maximum }\end{array}$ & Right & Left & $\begin{array}{l}\text { Thalweg or } \\
\text { maximum }\end{array}$ & Right & Left & $\begin{array}{l}\text { Thalweg or } \\
\text { maximum }\end{array}$ & Right \\
\hline 0.2-percent AEP flood & 1.0 & 2.7 & 1.6 & 3.1 & 5.9 & 3.4 & 5.0 & 12.8 & 6.8 \\
\hline 1-percent AEP flood & 0.9 & 2.5 & 1.7 & 3.1 & 5.8 & 3.3 & 4.4 & 13.4 & 5.3 \\
\hline 2-percent AEP flood & 0.9 & 2.3 & 1.6 & 2.9 & 5.7 & 3.2 & 4.3 & 13.1 & 5.0 \\
\hline 50-percent AEP flood & 0.3 & 1.1 & 0.7 & 1.3 & 3.9 & 1.8 & 5.3 & 10.0 & 5.9 \\
\hline March-April median monthly & $<0.1$ & 0.1 & 0.1 & 0.7 & 1.1 & 0.6 & 3.8 & 4.0 & 3.2 \\
\hline July-October median monthly & $<0.1$ & $<0.1$ & $<0.1$ & 0.2 & 0.2 & 0.1 & 0.8 & 1.7 & 1.3 \\
\hline Median of median monthlies & $<0.1$ & 0.1 & $<0.1$ & 0.4 & 0.7 & 0.3 & 1.4 & 3.0 & 2.4 \\
\hline
\end{tabular}


Table 20. Water velocities from the two-dimensional models at the dam approach and where the dam was once located at the Hughesville Dam study site in Warren Glen, New Jersey.

[AEP, annual exceedance probability]

\begin{tabular}{|c|c|c|c|c|c|c|c|c|c|}
\hline \multirow{2}{*}{ Discharge statistic } & \multicolumn{3}{|c|}{$\begin{array}{l}\text { Velocity at approach location with } \\
\text { dam, in feet per second }\end{array}$} & \multicolumn{3}{|c|}{$\begin{array}{l}\text { Velocity at approach location with- } \\
\text { out dam, in feet per second }\end{array}$} & \multicolumn{3}{|c|}{$\begin{array}{l}\text { Velocity at dam location without } \\
\text { dam, in feet per second }\end{array}$} \\
\hline & Left & $\begin{array}{l}\text { Thalweg or } \\
\text { maximum }\end{array}$ & Right & Left & $\begin{array}{l}\text { Thalweg or } \\
\text { maximum }\end{array}$ & Right & Left & $\begin{array}{l}\text { Thalweg or } \\
\text { maximum }\end{array}$ & Right \\
\hline 0.2-percent AEP flood & 4.2 & 5.7 & 4.2 & 11.2 & 12.7 & 6.9 & 8.7 & 14.6 & 9.6 \\
\hline 1-percent AEP flood & 3.4 & 4.7 & 3.4 & 9.6 & 11.2 & 5.1 & 7.2 & 13.2 & 7.7 \\
\hline 2-percent AEP flood & 3.0 & 4.3 & 3.1 & 8.9 & 10.5 & 5.8 & 8.4 & 12.6 & 6.8 \\
\hline 50-percent AEP flood & 1.5 & 2.4 & 1.4 & 4.8 & 6.4 & 4.4 & 5.1 & 9.4 & 5.6 \\
\hline March mean monthly & 0.4 & 0.8 & 0.4 & 1.8 & 2.8 & 1.7 & 3.4 & 6.0 & 4.3 \\
\hline April mean monthly & 0.4 & 0.8 & 0.4 & 1.8 & 2.8 & 1.7 & 3.4 & 6.0 & 4.3 \\
\hline May mean monthly & 0.3 & 0.6 & 0.4 & 1.5 & 2.5 & 1.5 & 3.0 & 5.7 & 3.8 \\
\hline August mean monthly & 0.2 & 0.4 & 0.2 & 1.1 & 1.8 & 1.5 & 3.7 & 5.1 & 2.5 \\
\hline
\end{tabular}

Table 21. Water velocities from the two-dimensional models at the outfall approach and culverts at the Wreck Pond Brook Outfall study site in Spring Lake, New Jersey.

[AEP, annual exceedance probability; $<$, less than]

\begin{tabular}{|c|c|c|c|c|c|c|c|c|c|}
\hline \multirow{2}{*}{ Discharge statistic } & \multicolumn{3}{|c|}{$\begin{array}{l}\text { Velocity at approach location } \\
\text { without culvert retrofit, } \\
\text { in feet per second }\end{array}$} & \multirow{2}{*}{$\begin{array}{l}\text { Velocity in } \\
\text { culvert without } \\
\text { culvert retrofit, } \\
\text { in feet per } \\
\text { second }\end{array}$} & \multicolumn{3}{|c|}{$\begin{array}{l}\text { Velocity at approach location } \\
\text { with culvert retrofit, } \\
\text { in feet per second }\end{array}$} & \multicolumn{2}{|c|}{$\begin{array}{l}\text { Velocity in culverts } \\
\text { with culvert retrofit, } \\
\text { in feet per second }\end{array}$} \\
\hline & Left & $\begin{array}{l}\text { Thalweg or } \\
\text { maximum }\end{array}$ & Right & & Left & $\begin{array}{l}\text { Thalweg or } \\
\text { maximum }\end{array}$ & Right & $\begin{array}{c}\text { Original } \\
\text { culvert }\end{array}$ & $\begin{array}{l}\text { New } \\
\text { culvert }\end{array}$ \\
\hline 0.2-percent AEP flood & 0.1 & 0.1 & $<0.1$ & 13.8 & 0.4 & 0.5 & 0.3 & 12.8 & 13.1 \\
\hline 1-percent AEP flood & 0.1 & 0.1 & $<0.1$ & 13.5 & 0.2 & 0.5 & 0.1 & 10.5 & 11.1 \\
\hline 10-percent AEP flood & $<0.1$ & 0.1 & 0.1 & 13.0 & 0.2 & 0.6 & 0.3 & 6.9 & 6.3 \\
\hline 50-percent AEP flood & 0.2 & 0.3 & 0.2 & 7.2 & 0.1 & 0.4 & 0.3 & 4.1 & 3.2 \\
\hline April mean monthly & 0.1 & 0.1 & 0.1 & 3.1 & 0.1 & 0.3 & 0.3 & 1.3 & 0.8 \\
\hline
\end{tabular}


Table 22. Fish passage criteria applied to study sites and results, for study reaches in Massachusetts, Rhode Island, Connecticut, and New Jersey.

[Prolonged swim velocity is the velocity that the fish can swim for 5 to 8 minutes. Burst swim velocity is the velocity that the fish can swim for up to 10 seconds. ft, foot; ft/s, foot per second; --, not applicable]

\begin{tabular}{|c|c|c|c|c|c|c|c|c|c|c|c|}
\hline Study reach & $\begin{array}{c}\text { Species } \\
\text { considered }\end{array}$ & $\begin{array}{l}\text { Discharge } \\
\text { statistic }\end{array}$ & $\begin{array}{l}\text { Minimum } \\
\text { depth } \\
\text { criterion, } \\
\text { in ft }\end{array}$ & $\begin{array}{l}\text { Depth } \\
\text { criterion } \\
\text { met? }\end{array}$ & $\begin{array}{l}\text { Maximum } \\
\text { prolonged } \\
\text { swim veloc- } \\
\text { ity, in ft/s }\end{array}$ & $\begin{array}{c}\text { Prolonged } \\
\text { swim velocity } \\
\text { criteria met } \\
\text { throughout } \\
\text { reach? }\end{array}$ & $\begin{array}{l}\text { Maximum } \\
\text { distance by } \\
\text { which pro- } \\
\text { longed swim } \\
\text { velocity is } \\
\text { exceeded, } \\
\text { in ft }\end{array}$ & $\begin{array}{l}\text { Velocity in } \\
\text { reach by } \\
\text { which pro- } \\
\text { longed swim } \\
\text { velocity is } \\
\text { exceeded, } \\
\text { in ft/s }\end{array}$ & $\begin{array}{l}\text { Is reach } \\
\text { exceeding } \\
\text { prolonged } \\
\text { swim } \\
\text { velocity an } \\
\text { obstacle } \\
\text { to fish pas- } \\
\text { sage? }\end{array}$ & $\begin{array}{l}\text { Maximum } \\
\text { burst swim } \\
\text { velocity, } \\
\text { in ft/s }\end{array}$ & $\begin{array}{c}\text { Burst ve- } \\
\text { locity cri- } \\
\text { teria met } \\
\text { through- } \\
\text { out } \\
\text { reach? }\end{array}$ \\
\hline Whittenton Dam & River herring & $\begin{array}{c}\text { April mean } \\
\text { monthly }\end{array}$ & 0.5 & Yes & 3 & No & 20 & 3 to 5 & No & 6 & Yes \\
\hline $\begin{array}{l}\text { West Britannia } \\
\text { Dam }\end{array}$ & River herring & $\begin{array}{c}\text { April mean } \\
\text { monthly }\end{array}$ & 0.5 & Yes & 3 & No & 15 & 3 to 4 & No & 6 & Yes \\
\hline $\begin{array}{l}\text { Hopewell Mills } \\
\text { Dam }\end{array}$ & River herring & $\begin{array}{l}\text { April mean } \\
\text { monthly }\end{array}$ & 0.5 & Yes & 3 & No & 100 & 3 to 6 & Yes & 6 & Yes \\
\hline Bradford Dam & River herring & $\begin{array}{c}\text { April mean } \\
\text { monthly }\end{array}$ & 0.5 & Yes & 3 & Yes & -- & -- & -- & 6 & Yes \\
\hline White Rock Dam & River herring & $\begin{array}{c}\text { April mean } \\
\text { monthly }\end{array}$ & 0.5 & Yes & 3 & Yes & -- & -- & -- & 6 & Yes \\
\hline Hyde Pond Dam & River herring & $\begin{array}{c}\text { April mean } \\
\text { monthly }\end{array}$ & 0.5 & Yes & 3 & No & 30 & 3 to 4 & No & 6 & Yes \\
\hline Pond Lily Dam & River herring & $\begin{array}{c}\text { March-April } \\
\text { median } \\
\text { monthly }\end{array}$ & 0.5 & Yes & 3 & No & 40 & 3 to 4 & Yes & 6 & Yes \\
\hline Hughesville Dam & $\begin{array}{c}\text { American } \\
\text { shad }\end{array}$ & $\begin{array}{l}\text { May mean } \\
\text { monthly }\end{array}$ & 1.0 & Yes & 4 & No & 190 & 4 to 6 & Yes & 8 & Yes \\
\hline $\begin{array}{l}\text { Wreck Pond Brook } \\
\text { Outfall }\end{array}$ & Alewife & $\begin{array}{l}\text { April mean } \\
\text { monthly }\end{array}$ & 0.5 & Yes & 3 & Yes & -- & -- & -- & 6 & Yes \\
\hline
\end{tabular}

${ }^{1}$ Only discharge statistic available for this site. 
indicated by the table, and velocities are often lower along the streambed; having this velocity obstacle is not an indicator of limited fish passage. The important result is that the burst swim velocities of the fish are not exceeded in any of the reaches.

A summary of the results for the study site reaches follows. The results include changes in the water-surface elevation of the 1-percent AEP discharge from the pre- to postdam-removal models, some of the similarities and differences between the one-dimensional and two-dimensional modeling results, and a brief discussion of fish passage criteria after the dam removal or the culvert retrofit.

\section{Whittendon Dam Study Site}

Removal of the Whittenton Dam decreased the 1-percent AEP water-surface elevation by 6.5 feet immediately upstream from the dam location according to the onedimensional model. The pre- and post-dam 1-percent AEP water-surface profiles did not converge until approximately 4,800 feet upstream from the dam location. The one- and two-dimensional pre-dam-removal models had similar results for the 1-percent AEP discharge; the two-dimensional model generated a water surface approximately 0.2 foot higher upstream from the dam. In the post-removal models of the 1-percent AEP discharge, the water surfaces from the one- and two-dimensional models were within 0.1 foot of each other immediately upstream from the dam location (table 4).

Based upon the two-dimensional model of the April mean monthly discharge, there were minimal barriers related to post-dam-removal fish passage. There was one stream segment that was nearly 20 feet long that exceeded the prolonged swim velocity of river herring, 3 feet per second. However, in this segment the maximum burst swim velocity of river herring was not exceeded (table 22).

\section{West Britannia Dam Study Site}

Removal of the West Britannia Dam decreased the 1-percent AEP water-surface elevation by 3.5 feet immediately upstream from the dam location according to the one-dimensional model. The pre-dam-removal and post-damremoval 1-percent AEP water-surface profiles did not converge until approximately 1,500 feet upstream from the dam location. The one- and two-dimensional pre-dam-removal models had similar results; the two-dimensional model generated a water surface approximately 0.1 foot lower upstream from the dam and diversion canal. However, for the post-dam-removal models, the water surface from the two-dimensional model was 0.7 feet above the one-dimensional model upstream from the diversion canal (table 5). The differences in these water surfaces were due to the models diverting different amounts of water down the diversion canal through the mill area adjacent to the dam. The resulting flows at the dam location were 1,374 and $1,386 \mathrm{ft}^{3} / \mathrm{s}$ for the one- and two-dimensional models, respectively.

Based upon the two-dimensional model of the April mean monthly discharge, there were minimal barriers related to fish passage. There were two stream segments up to 15 feet in length that exceeded the prolonged swim velocity of river herring, 3 feet per second. However, in this segment, the maximum burst swim velocity of river herring was not exceeded (table 22).

\section{Hopewell Mills Dam Study Site}

Removal of the Hopewell Mills Dam decreased the 1-percent AEP water-surface elevation by 10.4 feet immediately upstream from the dam location according to the one-dimensional model. The pre-dam-removal and postdam-removal 1-percent AEP water-surface profiles did not converge until approximately 1,800 feet upstream from the dam location. The one- and two-dimensional pre-dam-removal models had similar results for the 1-percent AEP discharge; the two-dimensional model generated a water surface approximately 0.2 foot higher upstream from the dam. In the postdam-removal models of the 1-percent AEP discharge, the two-dimensional model had a water surface 0.5 foot lower than the one-dimensional model upstream from the dam location (table 6).

Based upon the two-dimensional model of the April mean monthly discharge, there were substantial barriers related to fish passage. There were two stream segments up to 100 feet in length that exceeded the prolonged swim velocity of river herring, 3 feet per second. These reaches did approach the maximum burst swim velocity of river herring. These two reaches are in the upper end of what was the impoundment of the dam (table 22).

\section{Bradford Dam Study Site}

Removal of the Bradford Dam decreased the 1-percent AEP water-surface elevation by 0.2 feet upstream from the dam location according to the one-dimensional model. The minimal change in water-surface elevation was due to the dam being replaced by a series of weirs and the upstream weir being at an elevation comparable to that of the dam crest. This kept the impoundment above the site similar. The one- and two-dimensional pre-dam-removal models for the 1-percent AEP discharge had similar results; the two-dimensional model generated a water surface approximately 0.3 foot higher upstream from the dam. With the dam replaced by the weirs, water surfaces from the models matched upstream from the dam location (table 7). Based upon the two-dimensional model of the April mean monthly discharge, there were no barriers related to fish passage in the reach (table 22). 


\section{White Rock Dam Study Site}

Removal of the White Rock Dam decreased the 1-percent AEP water-surface elevation by 2.3 feet immediately upstream from the dam location according to the one-dimensional model. This change in water-surface-elevation results in little change to the inundation map (fig. 6) upstream from the dam for the White Rock Dam Study Site due to the topography along the river. The pre-dam-removal and post-dam-removal 1-percent AEP water-surface profiles did not converge within the 3,100 feet of river modeled upstream from the dam. The one- and two-dimensional pre-dam-removal models of the 1-percent AEP discharge had similar results; the twodimensional model generated a water surface approximately 0.6 foot lower upstream from the dam and diversion canal. The differences in the water surfaces were due to the models diverting different amounts of water down the diversion canal. The resulting flows over the dam were 4,105 and 3,353 ft $3 / \mathrm{s}$ for the one- and two-dimensional models, respectively. In the post-dam-removal models, the water-surface elevation from the two-dimensional model was 0.2 feet above that of the onedimensional model upstream from the diversion canal with the dam removed (table 8). Based upon the two-dimensional model of the April mean monthly discharge, there were no barriers related to fish passage with the dam removed (table 22).

\section{Hyde Pond Dam Study Site}

Removal of the Hyde Pond Dam decreased the 1-percent AEP water-surface elevation by 3.0 feet immediately upstream from the dam location according to the one-dimensional model. The pre-dam-removal and post-dam-removal 1-percent AEP water-surface profiles did not converge until about the 2,000 feet upstream from the dam. The one- and twodimensional pre-dam-removal models of the 1-percent AEP discharge had similar results; the two-dimensional model generated a water surface approximately 0.3 foot higher upstream from the dam. In the post-dam-removal models, the water surface was 0.1 foot lower in the two-dimensional model upstream from the dam location (table 9).

Based upon the two-dimensional model of the April mean monthly discharge, there were minimal barriers related to fish passage. There were stream segments as long as 30 feet in length that exceeded the prolonged swim velocity of river herring, 3 feet per second. However, in these segments, the maximum burst swim velocity of river herring was not exceeded (table 22). These stream segments were below the dam-removal site, and the velocities are not related to the removal of the dam.

\section{Pond Lily Dam Study Site}

Removal of the Pond Lily Dam decreased the 1-percent AEP water-surface elevation by 1.3 feet immediately upstream from the dam location according to the one-dimensional model. The pre- and post-dam 1-percent AEP water-surface profiles did not converge within the approximately 1,200 feet of river modeled upstream from the dam. The decrease in water-surface elevation also kept water within the levee-type feature that was along the west side of the channel, whereas before dam removal water spilled over the feature and ran down streets adjacent to the river. The levee-type feature elevations were based upon lidar data and the HEC-RAS model provided for pre-dam-removal conditions.

The one- and the two-dimensional pre-dam-removal models of the 1-percent AEP discharge had similar results; the two-dimensional model generated a water-surface approximately 0.3 foot higher upstream from the dam. In the postdam-removal models, the water-surface elevation was 1.3 foot lower in the two-dimensional model than the one-dimensional model upstream from the dam location (table 10). The reason for this unusually large difference was because the twodimensional model was computing supercritical flow at the previous dam location, whereas the one-dimensional model defaulted to critical depth at the dam location, resulting in greater backwater.

Based upon the two-dimensional model of the April mean monthly discharge, there were minimal barriers related to fish passage. There was one stream segment nearly 40 feet long and three roughly 20 feet long that exceeded the prolonged swim velocity of river herring, 3 feet per second. However, in these segments, the maximum burst swim velocity of river herring was not exceeded (table 22).

\section{Hughesville Dam Study Site}

Removal of the Hughesville Dam decreased the 1-percent AEP water-surface elevation by 7.6 feet at the approach to the dam location according to the one-dimensional model. The pre-dam-removal and post-dam-removal 1-percent AEP watersurface profiles did not converge within the approximately 1,300 feet of river modeled upstream from the dam location. The one- and the two-dimensional pre-dam-removal models of the 1-percent AEP discharge had similar results; the twodimensional model generated a water-surface 0.2 foot higher upstream from the dam. In the post-dam-removal models, the two-dimensional model had a water surface 0.9 foot lower upstream from the dam location than the one-dimensional model for the 1-percent AEP discharge (table 11).

Based upon the two-dimensional model of the May mean monthly discharge, there was a substantial barrier related to fish passage. There was a stream segment as long as 190 feet that exceeded the prolonged swim velocity of American shad, 4 feet per second. This is in a steep reach about 700 feet upstream from the removed dam's location. However, in this segment, the maximum burst swim velocity of American shad was not exceeded (table 22). 


\section{Wreck Pond Brook Outfall Study Site}

Installation of the additional culvert at the Wreck Pond Brook Outfall site decreased the 1-percent AEP water-surface elevation by 3.7 feet upstream from the dam location according to the one-dimensional model. This difference was also observed over 900 feet upstream from the outfall structure. The one- and two-dimensional models had similar results; the two-dimensional model generated a water surface approximately 0.1 foot higher upstream from the outfall, with and without the new culvert installation, for the 1-percent AEP discharge (table 12). Based upon the two-dimensional model of the April mean monthly discharge, there were no barriers related to fish passage with the new culvert installation (table 22).

\section{Summary}

Aquatic connectivity projects, such as removing dams and retrofitting culverts, have substantial benefits, such as decreased flood risk and increased fish passage. Modeling discharges at dam-removal sites and a culvert-retrofit site shows the effect of these projects. The U.S. Geological Survey, in cooperation with the U.S. Fish and Wildlife Service, used the U.S. Army Corps of Engineers Hydrologic Engineering Center's River Analysis System to model the sites in one- and two-dimensional hydraulics and found decreases in the 1-percent annual exceedance probability discharge water-surface elevation at all sites studied. The decreases in water-surface elevation ranged from 1.3 to 10.4 feet. One site, Bradford Dam, had only a 0.2 -foot decrease, but at that site the dam was replaced by a series of weirs to retain the upstream impoundment.

The differences found between the water-surfaceelevation results of the one- and two-dimensional models were minimal. However, the two-dimensional models provide the additional benefit of detailed velocity and depth mapping at a resolution not possible with a one-dimensional model. This velocity and depth data allow for assessment of the suitability of the sites for fish passage. Fish passage was improved at all the sites by removing the dams and retrofitting the culvert with only some barriers based upon the prolonged swim velocity capable of selected fish species.

\section{References Cited}

Ahearn, E.A., 2004, Regression equations for estimating flood flows for the 2-, 10-, 25-, 50-, 100-, and 500-year recurrence intervals in Connecticut: U.S. Geological Survey Scientific Investigations Report 2004-5160, 68 p., accessed March 16, 2020, at https://pubs.usgs.gov/sir/2004/5160/pdf/sir20045160.pdf.
Ahearn, E.A., 2010, Regional regression equations to estimate flow-duration statistics at ungaged stream sites in Connecticut: U.S. Geological Survey Scientific Investigations Report 2010-5052, 45 p., accessed March 16, 2020, at https://pubs.usgs.gov/sir/2010/5052/.

American Rivers, 2021, Restoring damaged rivers: American Rivers web page, accessed April 21, 2021, at https://americanrivers.org/threats-solutions/restoringdamaged-rivers/.

Bent, G.C., Steeves, P.A., and Waite, A.M., 2014, Equations for estimating selected streamflow statistics in Rhode Island: U.S. Geological Survey Scientific Investigations Report 2014-5010, 65 p., accessed March 16, 2020, at https://dx.doi.org/10.3133/sir20145010.

Brunner, G.W., 2016, HEC-RAS river analysis system 2D modeling user's manual: U.S. Army Corps of Engineers Computer Program Documentation 68-A, 171 p., accessed March 17, 2020, at https://www.hec.usace.army.mil/ software/hec-ras/documentation.aspx.

Capitol Region Council of Governments, 2017, Connecticut statewide LiDAR 2016: Capitol Region Council of Governments dataset, accessed March 11, 2020, at http://www.cteco.uconn.edu/data/flight2016/index.htm.

CivilGEO, Inc., 2020, GeoHECRAS: CivilGEO, Inc., software release, accessed March 11, 2020, at https://m.civilgeo.com/geo-hec-ras/.

Colarullo, S.J., Sullivan, S.L., and McHugh, A.R., 2018, Implementation of MOVE. 1 censored MOVE.1, and piecewise MOVE.1 low-flow regressions with applications at partial-record streamgaging stations in New Jersey: U.S. Geological Survey Open-File Report 2018-1089, 20 p., accessed March 17, 2020, at https://doi.org/10.3133/ ofr20181089.

England, J.F., Jr., Cohn, T.A., Faber, B.A., Stedinger, J.R., Thomas, W.O., Jr., Veilleux, A.G., Kiang, J.E., and Mason, R.R., Jr., 2018, Guidelines for determining flood flow frequency-Bulletin 17C (ver. 1.1, May 2019): U.S. Geological Survey Techniques and Methods, book 4, chap. B5, 148 p., accessed May 2019 at https://doi.org/ 10.3133/tm4B5.

Esri, 2020, ArcGIS Pro: Esri software release, accessed March 11, 2020, at https://www.esri.com/en-us/arcgis/ products/arcgis-pro/overview.

Federal Emergency Management Agency, 2013, 2011 Federal Emergency Management Agency topographic LiDAR - Quinnipiac River watershed, Connecticut: Federal Emergency Management Agency dataset, accessed March 11, 2020, at https://coast.noaa.gov/dataviewer/\#/ lidar/search/where:ID=1472. 
Flynn, K.M., Kirby, W.H., and Hummel, P.R., 2006, User's manual for program PeakFQ annual flood-frequency analysis using Bulletin 17B guidelines: U.S. Geological Survey Techniques and Methods, book 4, chap. B4, 42 p. [Also available at https://doi.org/10.3133/tm4B4.]

Hirsch, R.M., 1979, An evaluation of some record reconstruction techniques: Water Resources Research, v. 15, no. 6, p. 1781-1790. [Also available at https://doi.org/10.1029/ WR015i006p01781.]

Hirsch, R.M., 1982, A comparison of four streamflow record extension techniques: Water Resources Research, v. 18, no. 4, p. 1081-1088. [Also available at https://doi.org/ 10.1029/WR018i004p01081.]

Najarian Associates and Leon S. Avakian, Inc., 2015, Wreck Pond flood control berm and living shoreline conceptual plan and feasibility analysis: Wreck Pond Brook Watershed Technical Advisory Committee, prepared by Najarian Associates and Leon S. Avakian, Inc., 81 p., accessed March 13, 2020, at https://www.nj.gov/dep/wreckpond/ documents.htm.

National Centers for Environmental Information, 2005, Continuously updated digital elevation model (CUDEM) - 1/9 arc-second resolution bathymetrictopographic tiles: National Oceanic and Atmospheric Administration dataset, accessed March 12, 2020, at https://maps.ngdc.noaa.gov/viewers/bathymetry/ ?layers $=$ dem.

R Core Team, 2017, R-A language and environment for statistical computing: R Foundation for Statistical Computing software release, accessed March 13, 2020, at https://www.R-project.org/.

Rhode Island Geographic Information System, 2013, Digital elevation model-DEM11: Rhode Island Geographic Information System dataset, accessed March 11, 2020, at https://www.rigis.org/pages/2011-statewide-lidar.

Simeone, C.E., Olson, S.A., Taylor, N.J., Talbot, T.S., and Kinsey, J.M., 2021, Data and hydraulic models at selected dam removal and culvert retrofit sites in the northeastern United States: U.S. Geological Survey data release, https://doi.org/10.5066/P9LWIWVO.

U.S. Army Corps of Engineers, 2016, HEC-RAS River Analysis System-User's manual (ver. 5.0, February 2016): Davis, Calif., U.S. Army Corps of Engineers Hydrologic Engineering Center CPD-68, 960 p., accessed December 18, 2019, at http://www.hec.usace.army.mil/ software/hec-ras/.

U.S. Fish and Wildlife Service, 2019a, The Hurricane Sandy resilience program - Strengthening nature for people and wildlife: U.S. Fish and Wildlife Service fact sheet, 2 p., accessed November 19, 2020, at https://www.fws.gov/ hurricane/sandy/pdf/Hurricane-Sandy-Resilience-Programfact-sheet-v5-102919.pdf.
U.S. Fish and Wildlife Service, 2019b, Swim speed categories, in Fish passage engineering design criteria: U.S. Fish and Wildlife Service manual, Reference Plate 5-1, accessed November 19, 2020, at https:/www.fws.gov/Northeast/ fisheries/fishpassageengineering.html.

U.S. Geological Survey, 2012, USGS NED ned19_n40x25 w074x25_nj_3coastalcounties_2011 1/9 arc-second $201 \overline{2}$ $15 \times 15$ minute IMG: U.S. Geological Survey National Elevation Dataset, accessed March 13, 2020, at https://nationalmap.gov/viewer.html.

U.S. Geological Survey, 2015, USGS NED one meter x58y445 NJ SdL5 2014 IMG: U.S. Geological Survey National Elevation Dataset, accessed March 13, 2020, at https://nationalmap.gov/viewer.html.

U.S. Geological Survey, 2016, Coastal National Elevation Database (CoNED) Project - Topobathumetric digital elevation model (TBDEM): U.S. Geological Survey web page, accessed March 11, 2020, at https://www.usgs.gov/landresources/eros/coned.

U.S. Geological Survey, 2019, USGS 01108410 Mill River at Spring Street at Taunton, MA, in USGS water data for the Nation: U.S. Geological Survey National Water Information System database, accessed February 2019 at https://doi.org/ 10.5066/F7P55KJN. [Site information directly accessible at https://waterdata.usgs.gov/nwis/inventory/?site_no= 01108410.]

Watson, K.M., Collenburg, J.V., and Reiser, R.G., 2014, Hurricane Irene and associated floods of August 27-30, 2011, in New Jersey: U.S. Geological Survey Scientific Investigations Report 2013-5234, 149 p., accessed March 16, 2020, at https://dx.doi.org/10.3133/sir20135234.

Watson, K.M., and Schopp, R.D., 2009, Methodology for estimation of flood magnitude and frequency for New Jersey streams: U.S. Geological Survey Scientific Investigations Report 2009-5167, 51 p. [Also available at https://doi.org/ 10.3133/sir20095167.]

Zarriello, P.J., 2017, Magnitude of flood flows at selected annual exceedance probabilities for streams in Massachusetts: U.S. Geological Survey Scientific Investigations Report 2016-5156, 54 p., accessed February 2019 at https://doi.org/10.3133/sir20165156.

Zarriello, P.J., Ahearn, E.A., and Levin, S.B., 2012, Magnitude of flood flows for selected annual exceedance probabilities in Rhode Island through 2010 (ver. 1.2, revised March 27, 2013): U.S. Geological Survey Scientific Investigations Report 2012-5109, 81 p., accessed February 2018 at https://doi.org/10.3133/sir20125109. 

For more information about this report, contact: Director, New England Water Science Center

U.S. Geological Survey

10 Bearfoot Road

Northborough, MA 01532

dc_nweng@usgs.gov

or visit our website at

https://www.usgs.gov/centers/new-england-water

Publishing support provided by the

Pembroke Publishing Service Center 


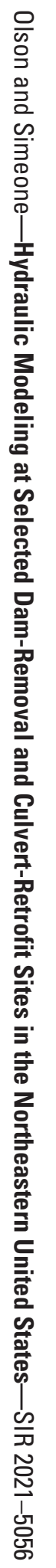

